\title{
Towards concurrent planning of railway maintenance and train services
}

\author{
Tomas Lidén
}


Towards concurrent planning of railway maintenance and train services Tomas Lidén

LIU-TEK-LIC 2016

ISBN 978-91-7685-774-8

ISSN 0280-7971

Linköping University

Department of Science and Technology

SE-601 74 Norrköping

Printed by LiU Tryck, Linköping, Sweden 2016 


\section{Abstract}

Efficiency in the public and freight transportation systems is of crucial importance for a society. Railways can offer high capacity and relatively low environmental impact, but require that several technical systems are tuned and operate well. Specifically there is a very tight interdependency between infrastructure and trains, which distinguishes railways from other transportation modes. Thus maintenance of all the subsystems is needed.

Railways do also have some specific and complicating properties that influence maintenance and operations: Most activities need exclusive access to the infrastructure and - due to the geographic layout, safety requirements and partitioning of the subsystems - large portions of the network will be affected by each activity. Furthermore, several organisational units and resources are involved, ranging from governments and regulatory bodies, over operators and contractors to suppliers, technical experts and work forces. Thus railway maintenance is complicated to organize and consumes large budgets.

This thesis treats the planning and scheduling problems that concern railway infrastructure maintenance and the coordination with train traffic. Mathematical methods and optimization are studied and used, with the aim of advancing the knowledge about models for solving such problems.

The thesis contains three papers and presents: (1) A survey regarding railway maintenance activities, the major planning problems and the conducted research so far; (2) A model for quantitative comparison and assessment of competing capacity requests from train operations and maintenance; (3) An optimization model for integrated scheduling of both maintenance windows and train services.

The work can be helpful for practitioners as well as researchers who want to take further steps in this interesting and challenging area. Based on the results that have been obtained, future research directions are presented that may lead towards practical use of concurrent planning of railway maintenance and train services. 



\section{Acknowledgments}

This work has been performed in the research project "Efficient planning of railway infrastructure maintenance", funded by Trafikverket with the grant TRV 2013/55886 in 2013 and approved for continuation in 2016. For both these decisions I am most grateful.

The project has been conducted within the national research program "Capacity in the Railway Traffic System" (kajt.org), which has given a good research environment with related projects and knowledge sharing at several seminars.

The history and inception of my $\mathrm{PhD}$ studies does however go back more than 10 years - a story which feels appropriate to share at this time. Even though I briefly considered an offer to continue with research when graduating 1986, it was not until 2005 that I started to seriously consider the possibility. At that time I had the privilege of being invited by Jesper Hansen to the optimization development team for the RailFleet system and while working with such skilled people as Jesper, Mattias Grönkvist, Jens Kjerrström and all the great people at Carmen/Jeppesen I was inspired to specialise in the field of optimization and computer science.

However, it proved rather difficult to set up a project and acquire funding for a 45-year old industry PhD and the thoughts were postponed until I moved to Transrail Sweden AB, where Per Leander encouraged me to make another try. Through my long time colleague Martin Joborn we made contact with Prof. Jan Lundgren at Linköping University who gave the excellent advice to first select a topic of my own interest. Finding that research idea which I felt strongly for proved invaluable when struggling with the "long and winding road" that lead to the project.

The idea of studying railway maintenance scheduling and giving increased attention to the situation for maintenance contractors dawned upon me sometime early 2010 after which Esbjörn Eriksson introduced me to the field. Then followed three failed applications (2010, 2011 and 2012) until the project idea was finally accepted as part of KAJT and I could, fully motivated, start my studies in August 2013 with Jan and Martin as my supervisors.

I am greatly indebted to all the people and organisations mentioned above and especially Transrail for generously supporting the idea, even though it is not within the company core business, allowing me to spend time on applications and preparations and finally letting me have a $20 \%$ part time position with full liberty in choosing my work hours.

During the project I have met with and learned tremendously from so many people that I cannot mention you all. A wealth of reference persons at Trafikverket, FSJ, BB-Rail, Strukton, InfraNord and Railcare has shared their knowledge of which Lars Brunsson and Per Hurtig deserves special mentioning. All the colleagues at KTS in Norrköping, especially the railway and public transport group, the other PhD students and the helpful admin- 
istration have given a stable and supportive environment. A special thanks go to my room mates Fahimeh Khoshniyat, Gerasimos Loutos and Therese Lindberg.

Finally, and most important, I thank my wonderful wife Sophia for her patience and loving support during all these years, and our lovely daughter Signe - the joy you bring is invaluable. Who knows, perhaps you can benefit from your dads efforts someday?!

I dedicate this thesis to the memory of my parents, Kristina and Helge, who regrettably cannot share this occasion.

Norrköping, May 2016

Tomas Lidén 


\section{Preface}

This is a thesis by publication comprising of three papers, two of which have been peer-reviewed and published, while the third one recently was submitted. The thesis itself puts these papers in a research context, summarises the work and provides some minor contributions by giving a deeper introduction to the field and more material regarding distinctive properties, planning concepts and processes concerning railway infrastructure maintenance. In addition the literature review has been updated with recent publications and complemented with tables that summarise modelling and algorithmic approaches used by other researchers.

\section{Papers included in the licentiate thesis}

Paper 1 : Lidén, T. (Oct. 2015). Railway infrastructure maintenance - a survey of planning problems and conducted research. Transportation Research Procedia 10C, 574-583.

doi:10.1016/j.trpro.2015.09.011

Paper 2 : Lidén, T., Joborn, M. (2016). Dimensioning windows for railway infrastructure maintenance: cost efficiency versus traffic impact. Journal of Rail Transport Planning \& Management 6.1, 32-47. doi:10.1016/j.jrtpm.2016.03.002

Paper 3 : Lidén, T., Joborn, M. (2016). An optimization model for integrated planning of railway traffic and network maintenance. Submitted to Transportation Research, part $C$ Special Issue on Integrated optimization models and algorithms in rail planning and control.

In papers 2 and 3, TL has performed all the research, modelling, coding, experiments and writing, while MJ has provided continuous support, modelling advice, reviewing and approval of the texts.

\section{Related publications not included in the thesis}

- Lidén, T. (2014). Survey of railway maintenance activities from a planning perspective and literature review concerning the use of mathematical algorithms for solving such planning and scheduling problems. Technical Report. Linköping University, Department of Science and Technology. http://urn.kb.se/resolve?urn=urn:nbn:se:liu: diva-111228

- Lidén, T. (april 2015). Samhällsekonomisk värdering av servicefönster på Norra Stambanan, sträckan Ockelbo-Ljusdal. Tech. Rep. PM, Dnr ITN-2013-00177, Linköping University, Dept of Science and Technology. http://kajt.org/onewebmedia/Va\%CC\%88rdering_Servicefo\% CC\%88nster.pdf 
The thesis makes extensive re-use of the survey report text (Lidén, 2014), especially in chapters 1-3.

\section{Dissemination}

The research has been presented at the following occasions:

Survey / paper 1

- Transportforum, 8-9 Jan 2014, Linköping

- Referensgruppsmöte, 24 Mar 2014, Norrköping

- KAJT-dagarna, 6-7 May 2014, Borlänge

- Nordic Seminar on Railway Technology, 14-15 Oct 2014, Bergen, Norway

- ITN PhD conference, 30 Oct 2014, Norrköping

- 18th Euro Working Group on Transportation, EWGT 2015, 14-16 July 2015, Delft, The Netherlands

Assessment / paper 2

- KAJT-dag om punktlighet, 13 Nov 2014, Stockholm

- Transportforum, 8-9 Jan 2015, Linköping

- KAJT-dagar, 6-7 May 2015, Borlänge

- CASPT, 19-23 July 2015, Rotterdam, The Netherlands

- Nationell transportforskningskonferens, 21-22 Oct 2015, Karlstad

Optimization model / paper 3

- Transportforum, 12-13 Jan 2016, Linköping

- KAJT-dagar, 26-27 April 2016, Borlänge 


\title{
Abbreviations
}

\author{
IM Infrastructure Manager \\ MC Maintenance Contractor \\ RU Railway Undertaking (or Train Operator)

\section{Terminology}

For explanations of railway, infrastructure and maintenance technical terms, we refer to library and online resources, such as Wikipedia (Glossary of rail transport terms). Language translations and term databases can be found at IATE (Inter-active Terminology for Europe) and RTRI (Railway Technical Terminology Dictionary). 



\section{Contents}

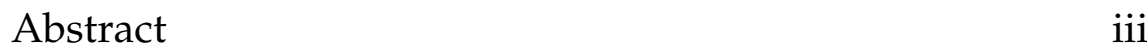

Acknowledgments $\quad \mathrm{V}$

Preface vii

Abbreviations ix

1 Introduction 1

1.1 Motivation 1

1.2 Vision 2

1.3 Scope and limitations $\quad 2$

1.4 Research questions 3

1.5 Methodology 3

1.6 Contributions 4

1.7 Thesis outline 5

2 Planning railway infrastructure maintenance $\quad 7$

$\begin{array}{lll}2.1 & \text { Specific properties of railway systems } & 7\end{array}$

2.2 Possessions and maintenance windows 10

2.3 Maintenance activities 11

2.4 Planning process 16

2.5 Concluding remarks 20

3 Literature survey 23

3.1 Planning problems 23

3.2 Reference statistics 24

3.3 Lines of research $\quad 26$

3.4 Concluding remarks 33

4 Research results 35

4.1 Survey of planning problems and conducted research 35

4.2 Assessment of costs and benefits 36 
4.3 Optimal scheduling of railway traffic and maintenance windows

5 Conclusions and future research 39

Bibliography 41

Paper 1: Survey 51

Paper 2: Assessment 63

Paper 3: Optimization model 83 


\section{List of Tables}

2.1 Possession time and planning horizon 14

2.2 Interview list 21

3.1 Planning problems and main stakeholders 24

3.2 Research publications over time 25

3.3 Research coverage $\quad 25$

3.4 Reference statistics 26

3.5 References about service life \& frequency determination 27

3.6 References about network design approaches 28

3.7 References about renewal scheduling and project planning 28

3.8 References about possession scheduling 29

3.9 References about deterioration-based maint. scheduling $\quad 30$

3.10 References about maint. vehicle routing \& team sched. $\quad 31$

3.11 References about work timing and resource scheduling 33 



\section{Chapter 1}

\section{Introduction}

This chapter starts by motivating the research and presents a vision of what to achieve. The research questions are then stated, followed by scope and limitations, the methodology used and a list of contributions. Finally, an outline of the subsequent chapters is given.

\subsection{Motivation}

Efficiency in the transportation systems is of great importance for a society. Railways can offer high capacity and relatively low environmental impact, but require that several technical systems like track, power distribution, safety, telecommunications and trains are tuned and operate well. Disturbances in any of these systems will degrade the service level. Moreover, failures or degradation in one may cause damages in the others. This is particularly true for track, trains and power distribution. Thus maintenance is essential for upholding reliability, transportation throughput and the benefits of the infrastructure system investments.

Railway infrastructure maintenance consumes large budgets, is complicated to organize and offer numerous challenging planning problems. Hence, large benefits can be realised if planning, scheduling and effectuation can be improved. In monetary volumes, the European countries are reported to allocate 15 - 25 billion EUR annually on maintenance and renewals for their railway systems consisting of about $300,000 \mathrm{~km}$ of track, giving an average spending of 70,000 EUR per km track and year (EIM-EFRTC-CER Working Group, 2012). As a comparison, the gross value added for the rail part of the transportation and storage sector is estimated to 35 - 55 billion EUR in the European Union (European Commission, 2012). Thus the maintenance spending amounts to more than $40 \%$ of the traffic value.

The figures in Sweden follow the same pattern: During the year 2014 a 
budget of 8,200 MSEK was used for maintenance and renewals of a 14,700 $\mathrm{km}$ track network, i.e $560,000 \mathrm{SEK} / \mathrm{km}$. In the same year the major passenger traffic operator (SJ AB) and freight traffic operator (Green Cargo AB) had a joint turnover of 13,200 MSEK. Thus the maintenance spending amounts to about $60 \%$ of the main traffic operator turnover in Sweden.

Train services and maintenance tasks should ideally be planned together, but has mostly been treated as two separate planning problems. Historically, practice and research about railway scheduling has however focused mainly on train operations and timetabling. The monetary volumes cited above shows that the value of maintenance has the same order of importance, which should encourage more research about such issues.

The amount of train paths and maintenance possessions also indicate the planning effort involved. For the year 2014, there were 7,200 train path and 2,200 possession applications in the Swedish yearly timetable process (Alexandersson, 2015). The total amount of train services was about 900,000. During the operative year an additional $16-17,000$ possessions were handled, along with a large number of train service changes $(32,000$ additions and 44,000 cancellations (Transport analysis, 2015)). These figures show the tremendous task that planners and involved parties are facing - a job that still relies mostly on manual work, with limited computational and scheduling support.

\subsection{Vision}

The aim of this work is to advance the knowledge and methods for planning and scheduling of railway infrastructure maintenance - specifically the coordination with train traffic. The research vision is to find optimization models and methods for integrated planning and scheduling of maintenance and traffic which can be put to practical use and which will improve efficiency for the complete railway system.

\subsection{Scope and limitations}

This work focuses on the coordination of train traffic and maintenance activities on a common railway infrastructure. The basic assumption is that both operative and maintenance tasks shall be scheduled together in a globally efficient way. Although the purpose of the infrastructure is to enable train traffic, the train operation may not always have precedence over maintenance. Instead they are both needed and dependent on each other - without maintenance the operation will in the end be impossible, without operation the maintenance is of no interest. Thus a healthy balance must exist, which should be reflected in the planning and scheduling methods and tools.

Less concern will be on how to perform the practical maintenance work itself. This is an equally important field of study, which may include effi- 
cient project planning, lean work organization approaches, automation of manual work, spare part planning, modular components etc. Degradation models will not be studied, nor how to find accurate estimates for the future maintenance needs. Instead the maintenance requirements are assumed to be given - perhaps with some uncertainty.

The initial step in this research was to perform an overview of the field, to identify the planning problems that exist and what previous research that have been done. In the next steps, focus has been on a new planning regime, which is being introduced in Sweden, called maintenance windows and on methods for dimensioning and scheduling them. Maintenance windows are predetermined train-free slots in the timetable, where all planned maintenance should be performed. Resource considerations have initially been excluded in our models, such as placements, volumes and scheduling of work crew, equipment and rolling stock.

\subsection{Research questions}

The following research questions are addressed:

Q1: Which are the major maintenance planning problems and what research has been conducted that uses mathematical optimization methods for solving them?

Q2: How can costs and effects on both maintenance and traffic be quantified when reserving train-free time windows for network maintenance in the timetable?

Q3: How can maintenance activities and timetabled traffic operation be coordinated on a common railway infrastructure with the use of scheduling optimization methods?

\subsection{Methodology}

The following methods have been used during this research:

Q1: Interviews, literature search

A series of unstructured interviews with planners, coordinators, technical experts and managers that are involved in planning and performing of infrastructure maintenance was conducted. The meetings (real life or over telephone) did not have a fixed questionnaire but focused on the following topics: How are the tasks planned and performed, what are the preconditions and effects of the task, what type of equipment and crew is involved, how long possessions are needed/wanted/gotten, what kind of coordination is done, what are the costs and amount of work, seasonal variations, suggestions for improvements etc. Each interview was documented with written notes, which the reference persons reviewed and corrected. 
Existing research was surveyed with a standard literature study from which a categorization was made and properties of the conducted research was collected.

Q2: Transport economy, cost-benefit analysis

For the assessment of costs and benefits when introducing maintenance window, three different models were used: maintenance costs were calculated with an analytical model, using standard calculus and implemented in a spreadsheet tool; freight traffic was treated by estimating scheduling adjustments, runtime changes and possible train service rejections in a simple timetabling model, implemented in MATLAB; passenger traffic was treated in a model based on existing methods from transport economics, implemented in a spreadsheet tool.

Q3: Mathematical modelling, optimization

A mixed integer optimization model was developed in an iterative approach, by documenting the mathematical formulation and coding it in Python, using OR-Tools as modelling layer and Gurobi as optimization solver. Logging and graphical visualisation was used when debugging and the test instances were generated directly in Python. Care has been taken to store the instances such that reproducibility shall be possible. Version control has been done with Git.

\subsection{Contributions}

The following contributions are made for each research question:

Q1a: Description of railway infrastructure maintenance from a planning perspective together with the planning process adopted in European countries.

Q1b: Listing and classification of the major planning problems concerning railway infrastructure maintenance.

Q1c: Survey of research publications regarding the use of mathematical models and optimization for solving the major railway maintenance planning problems.

Q2a: An analytical model for calculating the maintenance cost depending on available train free time.

Q2b: A framework for quantifying and comparing conflicting capacity requests from maintenance and traffic.

Q3a: Formulation of a mixed integer optimization model which jointly schedules train services and windows for infrastructure maintenance.

Q3b: Experimental studies showing that synthetic multi-day instances can be solved to near optimality within one hour of computation time. 


\subsection{Thesis outline}

The remainder of this thesis is organised as follows: Chapter 2 contains a thorough introduction to the planning of railway infrastructure maintenance. Chapter 3 presents a survey of research publications, categorized and mapped to the planning problem types. The chapter includes publications made until April 2016 and will therefore supersede the literature overview in Paper 1. Chapter 4 contains a summary of the results in Papers 1-3, while conclusions and future research directions are presented in Chapter 5. 



\section{Chapter 2}

\section{Planning railway infrastructure maintenance}

This chapter, which makes extensive re-use of texts from the survey report Lidén (2014), provides a deeper introduction to the planning of infrastructure maintenance. The first two sections are of general interest and needed for the remainder of the thesis. Section 2.1 describes important properties regarding railway systems and Section 2.2 explains the two central concepts "possessions" and "maintenance windows".

The subsequent sections contain findings that are free-standing and can be read for educational purposes. The material gives a deeper domain knowledge and is needed when considering real-life implementation of decision support tools, but can be skipped by readers with less interest in details. Section 2.3 discusses the scope and categorization of the various maintenance tasks, followed by a description of the contract types used by Trafikverket (the Swedish Transport Administration). Finally all the steps in the planning process for possessions and train paths are described in Section 2.4, followed by some concluding remarks in Section 2.5.

\subsection{Specific properties of railway systems}

This section lists some complicating aspects that affect maintenance and operation of railway systems, where the infrastructure consists of several sub-systems (track, power distribution, interlocking etc) that are spread out over vast geographic distances and which all must function properly. 
Activities are exclusive. Usually it is impossible to perform maintenance on the sub-systems used by the train services. Conversely it is normally not viable to operate trains where maintenance is conducted. If there are redundancies, such as parallel tracks, it might be possible to perform concurrent operation and maintenance on neighbouring parts of the network, usually with some sort of restrictions (e.g. speed reductions, safety distances). If so, network services can still be offered during maintenance although the service level might be degraded by requiring longer travel times, other routings etc. Rules and regulations will set the limitations for how this can be done. Some countries might allow maintenance work to be performed on parallel tracks if the train traffic obeys a certain speed limit (e.g. Sweden), while others might not allow any adjacent train traffic at all (e.g. The Netherlands). Some railway systems, such as certain subway or tram networks, might be able to close down operation completely during a couple of (night) hours, while others must operate more or less continuously.

Interdependency between infrastructure and trains. All rail guided transportation have a tight coupling between the fixed rail and the moving wheels, especially when having high weights and/or speeds, metal-metal contact and stiff axles - which practically all rail transportation has. The requirements and tolerances for the track are demanding, both regarding load-bearing (including suspension distribution from rail via sleepers and ballast to the substructure), levelling (lateral and transversal), gauge and displacement. Furthermore the rail surface quality greatly influences material fatigue and crack growth. All these properties affect the degradation, both for trains and track, as well as service quality. Equally important are the requirements and tolerances on the rolling stock (trains, locomotives, wagons and motor units). Flat wheels, slippage, locked brakes or bad roller bearings can cause extensive damages on the track and thus indirectly affecting other trains. For electrified railways there are high demands on the power distribution, both electrically (substation capability, motoring, electric braking, disturbances etc) and mechanically (catenary wire, pantograph etc). Finally, this tight interdependency between infrastructure and trains exists for the complete infrastructure, all rolling stock and the whole transport chain, which distinguishes railways from other transportation modes like shipping, air and road traffic.

Geographic layout of the network and its' components. Equipment and crews must be transported to more or less remote locations to perform maintenance. Some of these transportation activities must be done on the infrastructure itself and will thus consume traffic capacity. Furthermore, the different sub-systems, specifically signal interlocking and electrification, will be differently partitioned. Thus a maintenance activity that requires a section of the electrification or interlocking system to be turned off or blocked, will affect a larger part of the network than one that only requires 
a specific track or turnout to be blocked for traffic. The way the different sub-systems are partitioned and how these partitions match each other will therefore greatly influence the level of serviceability and maintainability.

Safety. Since trains have very long braking distances (far beyond the sighting distance) and run on tracks without possibility for any evasive manoeuvre, the safety requirements must be rigorous. Sufficient spacing and speed limitation must be guaranteed, both between trains, through turnouts and when approaching occupied or ending tracks. For the same reasons, safety is crucial when performing maintenance, such that integrity is guaranteed both for the work forces and for the trains that are allowed to pass the maintenance site.

Organization and deregulation. Several different functional units are involved in making a rail transportation possible, including legislation, design, construction, planning, procurement, infrastructure and rolling stock maintenance, marketing, selling, operation, service and education. Some enterprises cover several or most of these aspects - usually divided into geographical zones or traffic regions. Such large enterprises will always have organizational difficulties and cooperative challenges not only due to size, but also due to conflict of interests, economical incentives etc. In Europe a far reaching deregulation has been going on since the 1980s, with the overall purpose of opening up for commercial competition in several of the working fields. For infrastructure maintenance this trend has extended the use of Maintenance Contractors (MCs) which raises more concerns regarding contractual forms, public procurement and cooperation. The organizational split between Infrastructure Manager (IM), Railway Undertaking (RU) and $\mathrm{MC}$ affects responsibilities and how planning can be done.

Even without deregulation, railway maintenance and train traffic can be considered as orthogonal to each other, since the former is mainly tied to and organised in bounded geographical areas, while train traffic concerns transportation needs between distant regions. Thus, the responsibility for traffic and infrastructure is usually separated between organisational units, as well as the planning and scheduling of their respective tasks and resources. In such a setting, each party will treat the other type of activities as an unknown or given input and conflicts regarding track access will need some coordination or resolution procedure. Not surprising, there may be a lack of understanding and even mistrust between representatives for RUs, IMs and MCs. This situation will almost certainly result in solutions that are less good or even inefficient for one or more of the parties. 


\subsection{Possessions and maintenance windows}

All activities that require secure access to the railway infrastructure must obtain a (work) possession (RailNetEurope, 2013a). A possession shall guarantee that no trains will run on the designated area - usually coinciding with a signalling block, one or more tracks on a station or a complete station between the entry signals. The possession may also impose operative restrictions on neighbouring tracks. Depending on the capabilities of the train control system and how temporary speed limits are communicated, such restrictions may have to be imposed for a longer time period than the actual possession lasts. In addition, there might be speed restrictions after a work has been carried out until a "burn-in/settlement" period has elapsed.

Each possession is given a unique work id, in the same way as train paths receive unique train numbers, and they can span several days. Following is a fictitious example:

156630, from AH-22 to OF-11, M-F 06:30-07:55, M-F 10:10-11:25

where the id is 156630, the possession area is between signals AH-22 and OF-11 and the work is carried out on Monday to Friday between 06:30 and 07:55 as well as between 10:10 and 11:25, giving a total reserved time of $5 *$ $(1: 25+1: 15)=13 \mathrm{~h} 20 \mathrm{~m}$ divided into 10 schedule parts - allowing for some trains to pass between 08:00 and 10:00.

The possession area may be loosely given in the early planning stages and subsequently become more detailed. In fact, this is a challenge for the IM - to dimension appropriate possessions for the early capacity planning applications, before the project has been planned and possibly procured. The chosen possession will subsequently constrain the contractors that plan and perform the actual work. In effect the "possession design" will therefore impact the project cost for upgrading and renewal projects.

Throughout our work, we make a distinction between:

Major possessions which will (or is likely to) be in conflict with one or more train paths and hence require coordination

Minor possessions which do not affect the published train paths

Whether a possession is major or minor depends on several factors, such as the possession area and its duration, the time-of-day, the train traffic patterns and whether a published timetable exists or not. A very short possession can be considered major as soon as there is a conflict with a (wanted or scheduled) train path. Conversely a possession of several hours could be considered minor if no train paths will run on that part of the infrastructure the same day. Day-time possessions are usually more severe than on the night or over the weekend, while the work cost follows the opposite pattern.

The planning regime adopted in Sweden so far has been to let the MCs apply for the possessions, which usually is done as late as possible. If no 
room is reserved for maintenance in the timetable it can be difficult to find suitable possessions, which forces the MCs to perform their work on odd times and/or divide the tasks into small chunks which leads to inefficiency and cost increases. If the work cannot be split into smaller tasks, then the timetable must be altered and train operations rescheduled.

To increase the possibility for suitable work possessions, a new planning regime is being introduced, called maintenance windows, where the IM will propose regular, 2-6 h train free slots and/or longer maintenance closures before the timetable is constructed. Thus, the maintenance windows are given as an input to the yearly timetable process. Furthermore, the intention is to dimension and construct the maintenance windows before the procurement of maintenance contracts and keep them more or less unchanged during the contract period, giving stable planning and quotation conditions for the MCs. The goal is to perform almost all planned maintenance on work possessions within the stipulated maintenance windows.

Hence, the basic idea is to go from a situation with many, small and fragmented work possessions squeezed into an already published timetable (which causes changes and disturbances for the train operations), to a situation with few, large and regular maintenance windows preplanned before the timetable is constructed and the maintenance contracts procured. The overall aim is to increase efficiency, reduce cost as well as planning burden and also to improve robustness and punctuality.

\subsection{Maintenance activities}

This section discusses the definition of railway "maintenance", followed by alternate ways for categorizing the maintenance activities and a summary of the maintenance contract types that are used in Sweden.

\subsubsection{Definitions}

RailNetEurope (2013a) defines maintenance, renewals and upgrading as follows:

Maintenance Activity aiming to maintain something in good working order, prevent operational disturbance and/or uphold a given technical standard.

Renewal Any major substitution work on a subsystem or part subsystem which does not change the overall performance of the subsystem.

Upgrading Any major modification work on a subsystem or part subsystem which improves the overall performance of the subsystem.

The same document also notes that: 
As railway assets have a very long life, in practice renewal can mean the ongoing modernisation, or upgrading, of the railway network. This means that the distinction between 'renewal' (which in some countries, such as the UK, is part of the 'maintenance' budget) and 'capital investment' is not [..] easy to make.

Hence the distinction is not clear, neither between maintenance and renewals, nor between renewals and upgrading. This is also noted in a recent Swedish Government Official Report (Alexandersson, 2015). In practice a monetary limit is often used as guiding principle.

From a planning perspective the distinction between maintenance and renewals is less important, since both work types must be coordinated with traffic, although usually with different impact. Therefore we will not try to distinguish these types of work and simply use the word maintenance as a common term.

\subsubsection{Categorization}

Maintenance activities can be grouped and categorized in different ways. The classical way is to distinguish between preventive and corrective maintenance, but as will be shown, this distinction can be hard to make and is somewhat less appropriate when discussing planning problems. Maintenance organizations often make a more practically oriented categorization into diagnostic and restoring actions, but we will propose yet another approach, based on the capacity usage and planning horizon for different tasks.

Preventive vs corrective. The European standard EN 13306 for maintenance terminology divide maintenance into the terms preventive and corrective maintenance, for work taking place before and after a fault has been detected. Preventive maintenance is further divided into condition-based and predetermined maintenance, where the former uses measurements and inspections to determine when actions are needed and the latter uses fixed maintenance intervals/schedules. In addition to these categories Trafikverket uses the term operational maintenance ${ }^{1}$ for activities that handle normal operational conditions, although these activities are sometimes classified as corrective maintenance.

This categorization is mostly used for contractual, budgetary and followup reasons, but unfortunately the distinction can be somewhat arbitrary. Some examples of typical activities are as follows:

- Preventive

- Condition-based: measurements and inspection, grinding, tamping etc

\footnotetext{
1 "Drift" or sometimes "driftunderhåll" in Swedish
} 
- Predetermined: exchange of components such as light bulbs, batteries, signalling relays etc

- Corrective: fixing short circuits, repairing broken fasteners, welding, work after accidents etc

- Operational: snow removal, handling slippery rail etc

Tamping and grinding has been listed under preventive maintenance, which is normally true since mostly done well before any immediate action is needed. Occasionally, the deterioration is faster than anticipated and corrective tamping or grinding may however be needed.

For most condition-based maintenance, there are several intervention levels employed, stating the time frames for restoring actions. At the most serious level, immediate action is needed and operative restrictions may be imposed (lowered speed or train weights). Such immediate actions are considered corrective since the system is faulty (does not operate properly), although technically the components are not yet broken.

The above examples show that the same maintenance task may be categorized differently depending on the circumstances. Alexandersson (2015) also notes this problem and finds that the terminology and concepts are not consistently used between different organisations, regions and document types in Sweden.

Diagnostic vs restoring actions. The maintenance organizations tend to use a practically oriented classification, where activities are grouped into

- Diagnostic actions, which consists mainly of inspections and periodic measurements

- Restoring actions, which consists of all repairs, exchanges etc.

Bundling all restoring actions together is however not very descriptive, since it may include everything from large projects to small repair jobs. Hence a further subdivision is necessary.

Inspections and measurements will generate remarks, which have a time frame for when the restoring action should be performed. The remark does not specify exactly which action to take, just that a threshold limit has been reached and that an intervention is needed for returning the system to within the prescribed limits. If there are alternate actions, it is up to the $\mathrm{MC}$ to decide which action that is appropriate. Whichever is chosen will be influenced by the contractual form and sometimes negotiations are taking place between the MC and the IM before the final action is selected.

Capacity usage and planning horizon. From a planning perspective it is more appropriate to categorize the activities according to how much traffic capacity they consume and how long in advance they are planned. The 
Table 2.1: Possession time and planning horizon. Problematic cases marked with bold font.

\begin{tabular}{cll}
\hline Possession time & Activity & Planning horizon \\
\hline \multirow{2}{*}{$>8 \mathrm{~h}$} & Catenary wire replacement & $2-3$ years or urgent \\
& Track / turnout replacement & $2-3$ years \\
\hline \multirow{3}{*}{$4-8 \mathrm{~h}$} & Tamping of tracks & $1-2$ years or $\mathbf{1}$ month \\
& Grinding & $1-2$ years \\
& Switch replacement & $1-2$ years \\
& Catenary inspection \& & $2-3$ years \\
& maintenance & \\
\hline \multirow{3}{*}{$1-4$ h } & Tamping of turnouts & $1-2$ years or $\mathbf{1}$ month \\
& Ultra-sonic testing & $1-2$ years \\
& Fasteners, joints, rail repair .. & $1-2$ months or $\mathbf{1}$ week \\
\hline \multirow{2}{*}{ As train slots } & Periodic measurement & 1 year \\
& Fast grinding & 1 year \\
\hline \multirow{2}{*}{$0-1$ h } & Inspection & $0-2$ months \\
& Signal repair, vegetation etc & $0-2$ month \\
& Slippery rail, snow removal & 1 year or $\mathbf{0 - 1}$ week \\
\hline \multirow{2}{*}{ 1h - x days } & Accidents, urgent repair & none \\
\hline
\end{tabular}

possession time gives a local measure of the capacity usage, although the possession may influence larger parts of the network depending on the topology and train service design, resulting in a greater system traffic impact. Ideally the highly disruptive actions (requiring very long and exclusive access to the track) should be planned long in advance while actions requiring less possession time can be planned in later stages. In Table 2.1 the different activities are listed according to the needed amount of possession time (per task) and how long in advance the planning can be done.

Problematic cases (marked with bold font in the table) are those that require long possession time but have a short planning horizon:

- Catenary wire replacements are highly disruptive and can usually be planned well in advance. But the degradation can in some cases be very quick, especially if the pantographs of the trains are worn, which may lead to urgent need for replacement or repair.

- Tamping can normally be planned well in advance but in cases where preventive maintenance have been neglected tamping might be needed with short notice.

- Rail repair are often due to cracks found by ultra-sonic testing, which may be given with short notice. In severe cases the possession time might be $4-6$ hours. 
- Accidents and urgent repair may result in possessions ranging from hours up to several days.

Most maintenance activities are planned and scheduled in the capacity planning processes, such that their possessions are included in the daily operational timetable which is handed over to the traffic control centers (see Section 2.4.6). Some activities may however be carried out directly in the operative phase. Two types of cases are handled in this way:

- Accidents and urgent repair, which are triggered by external events and are managed by the traffic control center.

- Small and quick maintenance tasks, which are triggered and managed by the MCs. These tasks can either be secured by (a) possessions given directly by the traffic dispatcher, or (b) a manual train warning procedure handled by the work force itself. The latter handling is hazardous, especially for sections with high-speed traffic, and the use of it is discouraged.

\subsubsection{Contract types}

The Swedish railway maintenance market has undergone a quick deregulation since 2001 (Trafikverket, 2012). Today all railway maintenance work on the national infrastructure is performed in contracts signed after open competitive tendering. Three types of maintenance contracts are used (upgrading and investment projects are disregarded here):

Renewal projects, where parts of the infrastructure is re-established to its intended standard. Typical examples can be the replacement of catenary wires, track sections and turnouts. A contract is signed for each project.

National maintenance contracts. These contracts are used for activities that are performed with a limited but expensive and/or highly specialized set of equipment and crew that operate over the whole infrastructure network. Typical examples are the periodic track geometry measurements, ultra-sonic testing and grinding. The contract lengths are 3-5 years with a prolongation of 2 or $2+2$ years. One contract is set up for each distinctive type of activity.

Regional maintenance contracts. These contracts are used for all remaining activities including inspection, predetermined activities, corrective maintenance etc. The contract length is usually 5 years with a prolongation of 2 or $1+1$ years. The infrastructure network is divided into 30-40 such contracts.

Trafikverket re-evaluate and revise the contractual forms continuously, but the wish is to move more responsibility to the contractors. This requires revising the specifications from a detailed component/technical level to a 
system/functional level. Performance-based contracts have been proposed in research literature as a method for increasing efficiency (Famurewa et al., 2012; Lingegård, 2014) and positive experiences have been reported from countries like The Netherlands. Alexandersson (2015, Section 8.3.2, pp. 130) discusses when traditional or functional (performance-based) contracts are suitable and find that the latter (i) requires a deeper knowledge about the infrastructure state, (ii) will allocate the risks differently and (iii) might not increase the amount of preventive maintenance as much as hoped for.

\subsection{Planning process}

This section describes the complete planning process for obtaining possessions and train operation slots as it works in Sweden today. The process follows EU guidelines and should be quite similar throughout the European countries up till the publication of the yearly timetable. The subsequent steps might differ more between different countries.

The process is divided in the following steps:

1 Freight corridor planning, where so called prearranged paths for the international freight trains are established and coordinated with the major possessions (large infrastructure maintenance activities).

2 Preparation and publishing of the network statement, which shall contain all major possessions that the train operating companies should adhere to.

3 Yearly timetable planning, where the regular timetable for all train paths are planned together with the major work possessions.

4 Timetable revision planning, where all dated timetable adjustments are made and final coordination of train paths and possessions should be done.

5 Planning of minor possessions, where plannable work which do not require any train path adjustments are scheduled.

6 Operational planning and control, where the traffic control center will make operative adjustments, authorize unplanned possessions and control all activities (train runs and work) on the railway infrastructure.

The first five steps make up the capacity planning process, while the last step is the operational phase. In steps 1-4 timetable adjustments and conflicts between different requests are handled, while in step 5 only requests for "spare" capacity should be handled - for the planned tasks. Urgent repair may however break the normal flow and require major replanning in steps $5-6$.

We will now describe all the steps in greater detail, specifying the process as it is intended according to guidelines and regulations, while noting any known deviations from the target process. For each planning step, the criteria for which possessions to consider are stated. 


\subsubsection{Freight corridor planning}

A number of rail freight corridors (RFC) exist in Europe and to secure a stable rail freight service across them, the traffic is run on so called prearranged paths $(\mathrm{PaP})$. These $\mathrm{PaPs}$ belong to the $\mathrm{RFC}$ and have priority over the regular (national) timetables. The planning of PaPs and major possessions affecting them, follow the guidelines given in RailNetEurope, 2013b. The PaPs are planned roughly one year ahead of the yearly timetable planning and the RFC should organize two coordination meetings per year: in November and in May, where all concerned IMs and RUs shall participate. Since the appropriate major possessions should be known to the RUs when making their PaP requests, the specified deadlines are as follows:

- In December, T-24m² ${ }^{2}$, the major possessions should be initially given

- In July, T-17m, the initial PaP applications should be given as well as any further information regarding the possessions, after which the IMs shall construct the PaPs (starting in August, T-16m)

- In December, T-12m, the final coordination of the possessions and the PaPs shall be done

- In January, T-11m, the PaPs should be published (no later than 3 months before the final date for requesting capacity in the yearly timetable planning)

Thus the PaPs are published one month after the network statement. After publication, the PaPs and the possessions may be updated (after coordination between IMs and RUs) in March, T-9m (one month prior to the final date for train path requests), and in August, T-4m (one month prior to the final allocation of train paths).

The criteria for which possessions to include in the RFC coordination are that they will either (a) cause significant changes in the timetable such as rerouting of trains or delays of more than 60 minutes, (b) cause a permanent closure of more than 7 days in a row or (c) are partitioned in temporal closures or operational restrictions for more than 30 days in a row. Larger possessions should be coordinated early while smaller ones may be handled in the later stages of the process.

\subsubsection{Preparation of the network statement}

The network statement sets the prerequisites for a timetable period and thus lays the ground for the yearly timetable planning process. It shall be published in December, T-12m, and shall contain all major possessions that the RUs are expected to adhere to in their planning and train path requests. The deadlines are as follows:

\footnotetext{
${ }^{2}$ The notation $\mathrm{T}-24 \mathrm{~m}$ denote 24 months before the timetable $\mathrm{T}$ starts
} 
- In August, T-16m, all major possessions should be given

- In October, T-14m, coordination meetings between the IM and the RUs are taking place regarding the major possessions

- In December, T-12m, the network statement is published

There are general criteria for which major possessions that should be included in the network statement, but a final decision is taken for each individual case.

\subsubsection{Yearly timetable planning}

In the yearly timetable planning, all regular train paths and major possessions should be entered and coordinated. However, the regular timetable is created for one or more typical weeks and with the current planning tools in Sweden it is not feasible to perform a complete coordination and traffic adjustment for all known possessions, since it would require a dated planning for more or less the complete year.

For handling of the possessions, the deadlines are as follows:

- In February, T-10m, all the wanted (major) possessions initiated by the IM should be given. For MCs the final deadline is April, T-8m

- During April to August, T-8m - T-4m, coordination meetings take place between the IM, RUs and MCs regarding the upcoming timetable period $\mathrm{T}$

- In June, T-6m, a proposal for the major possession plan (together with the preliminary regular timetable) is published.

- In September, T-3m, the major possession plan (together with the final regular timetable) is published

The criteria for which possessions to request in the yearly timetable process is not firmly stated, but durations of $4-6$ hours or longer is a common rule-of-thumb.

\subsubsection{Timetable revision planning}

The complete dated planning is performed in the revision planning, which includes making adjustments to train paths, handling all conflicts between different requests as well as adding and removing train paths and possessions. Special weekend or holiday traffic is handled as well as changes from RUs and MCs. This is the final step where planned major possessions should be handled.

Trafikverket currently performs four revisions which divide the timetable into roughly the following periods: 
R1: December to March, which is settled about 8-10 weeks before (R1-10w - R1-8w), i.e. in October (T-2m)

R2: April to June, settled about R2-10w, i.e. in the end of January

R3: July to September, settled about R3-10w, i.e. in the end of April

R4: October to December, settled about R4-15w, i.e. in the middle of June (before the major vacation period starts)

The ambition is that all major possessions shall be coordinated and settled with the affected RUs and MCs no later than 12-14 weeks before the actual operating day (or week) - a time limit that is not always kept. The limit is set so as to give reasonable time for the RUs to plan their fleet circulations, crew schedules as well as handling changes in booking systems and towards customers.

\subsubsection{Planning of minor possessions}

The final tactical planning step is a continuous process which handles a rolling 8 week period, with weekly increments/handover. The deadlines concerning a specific operating week $\mathrm{W}$, are as follows:

- $\mathrm{W}-2 \mathrm{w}$ is the latest time for application of a possession. Apart from the possession application, all work plans and safety documents must be finalized at this time. The planner shall then verify that there are no train conflicts, that all paper work is in order etc.

- $\mathrm{W}-1 \mathrm{w}$ the possessions should be approved and the plan locked, normally on Thursday for the upcoming week starting on Monday.

The compliance to these deadlines varies. For traffic intense areas (around the major cities) the time limits are well respected while it is less so at other areas. It might even occur that possessions are registered and approved as late as one day before the actual work day.

As noted previously, urgent repairs may break this flow and require major possessions, with subsequent replanning of both trains and possessions.

\subsubsection{Operational planning and control}

One day before the operational day (D-1d) all necessary documents are generated (daily train graph and possession descriptions, including contact info, safety informations etc) and responsibility is handed over to the traffic control centers, which will treat them as part of the real-time dispatching.

During the operational day (D), unplanned possessions are authorized using a manual procedure (called direct planning), where the dispatcher documents the possession by completing a form, including work id, contact information, description etc. This is done on paper except at one control center where it's included in an electronic train graph system. 
Whenever accidents or situations that require urgent repair happen, the following procedure is used:

1 The dispatcher makes an error report and alerts the operating technician who in turn will contact the appropriate MC.

2 The maintenance crew shall immediately (within a contractually agreed time limit) move to the problematic location, make an inspection and return with a proposed repair plan (including time estimates).

3 Meanwhile, the dispatcher handles the acute situation and prepares reduction plans.

4 Once the $\mathrm{MC}$ has given a proposed repair plan, the traffic control center can make a complete replanning for the train traffic, passengers and repair work. It can be a delicate balancing act to handle all requests from passengers and freight customers, RUs and MCs in a reasonably efficient way.

5 Once the repair work is finished, a recovery plan is needed in order to re-establish a normal traffic situation.

Currently there are no decision support tools that assist the dispatchers in this cumbersome task. However, at one traffic control center, pre-made reduction plans are used. This is helpful, since the decisions will be quicker, more detailed and easier to communicate (when a suitable plan exists). Furthermore the reduction plans can be better prepared, since they are done under calm conditions and by involvement of several stake holders.

\subsection{Concluding remarks}

The material in this chapter is largely based on a series of unstructured interviews with planners, coordinators, technical experts and managers that are involved in planning and performing of infrastructure maintenance - as listed in Table 2.2. Most of the reference persons represent Trafikverket but several persons at MCs were also interviewed.

As has been discussed, railway infrastructure maintenance is complicated to organise and coordinate with the train traffic. The central concepts of "possessions" and "maintenance windows" have been explained and will be used frequently in the remainder of the thesis. For planning purposes the traditional categorization into preventive and corrective maintenance is less appropriate and instead it has been suggested to treat the activities according to the traffic capacity impact they have and how long in advance they can be planned. Finally, a detailed description of the planning process for obtaining possessions and train paths have been presented, which gives a baseline for future process improvements and development of supporting tools. 
The planning problems addressed in Paper 2 and 3 of this thesis concerns long term tactical planning on an aggregated network scale, that primarily will be done during Freight corridor planning and Preparation of the network statement. The methods are also applicable for cost-benefit analysis studies and in capacity studies where train services and maintenance activities should be planned together.

Table 2.2: Interview list $(\operatorname{TrV}=$ Trafikverket)

\begin{tabular}{|c|c|c|c|}
\hline Place & Name & Organisation & Subject \\
\hline 2013-09-10 Phone & G. Styhr & $\operatorname{TrV}$ & $\begin{array}{l}\text { Maint. projects, ongoing develop- } \\
\text { ment }\end{array}$ \\
\hline 2013-10-17 Malmö & L. Brunsson & $\operatorname{TrV}$ & Overview, maint. windows \\
\hline 2013-10-17 Malmö & S. Gagzis & $\operatorname{TrV}$ & Procurement, contractual forms \\
\hline 2013-11-05 Gävle & F. Eriksson & $\operatorname{TrV}$ & Planning, coordination, processes \\
\hline 2013-11-07 Solna & T. Modén & InfraNord (MC) & Maint. contracting \\
\hline 2013-11-12 Phone & S. Andersson & $\operatorname{TrV}$ & $\begin{array}{l}\text { Minor possession planning, traffic } \\
\text { control }\end{array}$ \\
\hline 2013-11-26 Phone & L. Brunsson & $\operatorname{TrV}$ & Freight corridors, maint. volumes \\
\hline 2014-01-14 Malmö & H. Hansson & Strukton (MC) & $\begin{array}{l}\text { Maint. contracting, statistics, com- } \\
\text { mon problems }\end{array}$ \\
\hline 2014-01-17 Stockholm & D. Öholm & $\begin{array}{l}\text { FSJ/Railcare } \\
(\mathrm{MC})\end{array}$ & $\begin{array}{l}\text { Preventive maint., snow clearing, } \\
\text { organisation }\end{array}$ \\
\hline 2014-02-03 Phone & M. Syk & $\operatorname{TrV}$ & Ultrasonic testing \\
\hline 2014-02-03 Phone & S. Bäckström & $\operatorname{TrV}$ & $\begin{array}{l}\text { Periodic meassurment, track geom- } \\
\text { etry }\end{array}$ \\
\hline 2014-02-12 Phone & S. Kallander & $\operatorname{TrV}$ & Grinding \\
\hline 2014-02-28 Phone & R. Lindberg & $\operatorname{TrV}$ & $\begin{array}{l}\text { Catenary wire, power distribution, } \\
\text { inspection }\end{array}$ \\
\hline 2014-03-10 Phone & H. Johansson & $\operatorname{TrV}$ & Catenary wire maint. \\
\hline 2014-03-10 Phone & T. Nordmark & LKAB (RU) & Freight traffic, Malmbanan \\
\hline 2014-10-29 Phone & L. Henriksson & InfraNord (MC) & Work costs \\
\hline
\end{tabular}





\section{Chapter 3}

\section{Literature survey}

This chapter contains a literature study, that is an extension and continuation of Lidén (2014, Section 5), which in turn was summarised in the literature overview of Paper 1. Therefore this chapter supersedes Section 3 of Paper 1, by providing more details and including research references made public until April 2016.

Section 3.1 briefly repeats the catalogue of planning problems from Paper 1, while Section 3.2 gives some overview statistics for the listed references. Then the different lines of research are presented, with detailed descriptions and overview tables regarding the model approaches and techniques used, in Section 3.3. Finally, some concluding remarks are made in Section 3.4.

Sections 3.1 and 3.2 are of general interest, while the remainder is intended for readers with detailed interest in a specific research area.

\subsection{Planning problems}

We have identified 9 major planning problems, which are further described in Section 2 of Paper 1. The problem types are classified as strategic, tactical or operational and are listed in Table 3.1 with their main stakeholders (Infrastructure Manager (IM) or Maintenance Contractor (MC)). The strategic class concerns dimensioning, localisation and organisation, with time horizons of one to several years. Tactical problems include scheduling, timetabling and construction of plans covering a medium long time horizon (weeks to a couple of years), often handling resources as categorized, anonymous objects. The operational planning problems concern implementation and effectuation, covering short time horizons (hours to months), usually handling the real resources.

Apart from the 9 major planning problems, some other aspects are discussed, which cuts over several problem types, namely robustness and real- 
Table 3.1: Planning problems and main stakeholders

\begin{tabular}{lll}
\hline Class & Problem & Stakeholder \\
\hline \multirow{3}{*}{ Strategic } & Maintenance dimensioning & IM \\
& Contract design & IM \\
& Resource dimensioning and localisation & MC \\
\hline \multirow{3}{*}{ Tactical } & Possession scheduling & IM, (MC) \\
& Vehicle \& team routing & $(\mathrm{IM}), \mathrm{MC}$ \\
& Rescheduling & $\mathrm{IM}$ \\
\hline \multirow{3}{*}{ Operational } & Maintenance project planning & MC \\
& Work timing \& resource scheduling & MC \\
& Track usage planning & IM, MC \\
\hline
\end{tabular}

time control. The aspect of robustness could be considered in all of the problems, since uncertainty always is prevalent. The real-time control situation has several challenging dispatching and replanning problems regarding error reports, incidents and maintenance which calls for coordination between train services and work crews. The MCs must also be able to assign and schedule suitable resources to unforeseen work tasks in a way that assures an appropriate level of preparedness and response time. Paper 1 suggests scenario planning as a method for preparing recovery or reduction plans before day of operation rather than solving these problems directly in the real-time control situation.

\subsection{Reference statistics}

More than 70 research references is presented in this chapter, grouped into lines of research. As an introduction we start by giving some overview statistics regarding publication history, problem type coverage, techniques and data used.

History. Table 3.2 shows the lines of research and how the number of publications have evolved over time, which reveals the very limited amount of research done before 2000, but also a steady increase of publications since 2005.

Coverage. A mapping between the problem types and conducted research is shown in Table 3.3. Roughly $35 \%$ of the publications concern strategic, $55 \%$ tactical and $10 \%$ operational problems. Out of the 9 problem types, 4 have several research publications, 2 are partially treated (shown with parenthesized counts) and for the remaining 3 no references have been found. Thus, several interesting problem areas can be identified where optimization methodology have not yet been applied, such as contract design, 
Table 3.2: Research publications over time

\begin{tabular}{llrrrrrrr}
\hline \multirow{3}{*}{ Class } & Line of research & - & 1990 & 2000 & 2005 & 2010 & 2015 & \\
& 1989 & 1999 & 2004 & 2009 & 2014 & - & Total \\
\hline \multirow{3}{*}{ Strat. } & Service frequency & 1 & & & 7 & 4 & 3 & 15 \\
& Network design & & & & & 2 & 1 & 3 \\
& Renewal scheduling & & & 1 & 1 & 4 & 2 & 8 \\
\hline \multirow{2}{*}{ Tact. } & Possession scheduling & \multirow{2}{*}{1} & 2 & 3 & 3 & 6 & 1 & 15 \\
& Deterioration-based sched. & 1 & & 1 & 1 & 5 & 4 & 12 \\
& Vehicle \& team routing & & & & 1 & 8 & 5 & 14 \\
\hline \multirow{2}{*}{ Oper. } & Work timing & & 1 & & 1 & 4 & 1 & 7 \\
\hline & \multicolumn{1}{c}{ Total } & 2 & 3 & 5 & 14 & 33 & 17 & 74 \\
\hline
\end{tabular}

Table 3.3: Research coverage

\begin{tabular}{lllc}
\hline Class & Problem type & $\begin{array}{l}\text { Line of research } \\
\text { (references) }\end{array}$ & $\begin{array}{c}\text { Number of } \\
\text { publications }\end{array}$ \\
\hline \multirow{5}{*}{ Strat. } & Maintenance dimensioning & $\begin{array}{l}\text { Service frequency } \\
\text { Network design }\end{array}$ & 15 \\
& Contract design & Renewal scheduling & 3 \\
& Resource dim. \& localization & (Peng et al., 2013) & 8 \\
\hline \multirow{3}{*}{ Tact. } & Possession scheduling & Possession scheduling & - \\
& Vehicle \& team routing & Deterioration-based sched. & 15 \\
& Rescheduling & Vehicle \& team routing & 12 \\
\hline \multirow{3}{*}{ Oper. } & Project planning & - & 14 \\
& Work timing \& resource sched. & Work timing & - \\
\cline { 2 - 4 } & Track usage & - & 7 \\
\hline
\end{tabular}

resource dimensioning and localization, rescheduling, project planning and track usage. Other aspects and approaches that have attracted little amount of work so far, are robustness and real-time operational control.

Approaches. From the detailed descriptions and tables in Section 3.3 the statistics in Table 3.4 have been compiled, which shows that:

- Single objective approaches are most common

- Exact and heuristic optimization models are equally common

- Real input data is used in $3 / 4$ of the cases

- Line and network instances are equally common. 
Table 3.4: Reference statistics

\begin{tabular}{lcccc}
\hline Line of research & $\begin{array}{c}\text { Objective } \\
\text { Single }: \text { Multi }\end{array}$ & $\begin{array}{c}\text { Optimization } \\
\text { Exact : Heur. }\end{array}$ & $\begin{array}{c}\text { Input data } \\
\text { Theor. : Real }\end{array}$ & $\begin{array}{c}\text { Railway type } \\
\text { Line : Network }\end{array}$ \\
\hline Service frequency & $10: 5$ & $11: 4$ & $3: 12$ & $12: 3$ \\
Network design & $3: 0$ & $3: 0$ & $0: 3$ & $0: 3$ \\
Renewal scheduling & $6: 2$ & $3: 5$ & $4: 4$ & $5: 3$ \\
Possession scheduling & $15: 0$ & $6: 9$ & $4: 11$ & $8: 7$ \\
Deterioration-based sch. & $11: 1$ & $8: 4$ & $1: 11$ & $10: 2$ \\
Vehicle \& team routing & $14: 0$ & $2: 12$ & $4: 10$ & $1: 13$ \\
Work timing & $7: 0$ & $3: 4$ & $3: 4$ & $1: 6$ \\
\hline Total (count) & $66: 8$ & $36: 38$ & $19: 55$ & $37: 37$ \\
Share (\%) & $89: 11$ & $49: 51$ & $26: 74$ & $50: 50$ \\
\hline
\end{tabular}

\subsection{Lines of research}

This section describes a large number of references, grouped into lines of research. For each line of research, we give an overview description and a summary table, that lists all the references with information about modelling, techniques and data. Finally a textual description of each reference is given. For publications included in Paper 1, we refer to the descriptions presented in Lidén (2014) rather than repeating the same texts here. Some of the works made public after 2014 have been included although they are preprints or not yet published.

In the reference tables, the notation $\langle$ period length $\rangle /\langle$ time step $\rangle$ is used for describing the length of the schedule and the time resolution. Thus, $1 \mathrm{~m} / 1 \mathrm{~d}$ shall be interpreted as a schedule horizon of one month divided into 1 day time slots.

\subsubsection{Strategic problems}

Three lines of research regarding strategic problems have been identified, labelled as (1) Service life and maintenance frequency determination, (2) Network design considering maintenance, and (3) Renewal scheduling and upgrade project planning.

Service life and maintenance frequency determination - Table 3.5

The service life of different components will determine the long term economy together with policies for inspection, preventive maintenance and renewal intervals. In this line of research, life-cycle cost models are commonly used, which consider a standard unit of track with some given traffic load. The studies either aim at condition-based maintenance, where focus is on inspection planning, or prescribed / preventive maintenance, where focus is on maintenance and renewal intervals. 
Table 3.5: References about service life \& frequency determination

\begin{tabular}{|c|c|c|c|}
\hline Reference & Model & Activity & Details \\
\hline Lamson et al. (1983) & $\begin{array}{l}\text { 1: Dynamic progr. } \\
\text { 2: LCC }\end{array}$ & $\begin{array}{l}\text { 1: Grinding } \\
\text { 2: Rail repair }\end{array}$ & $\begin{array}{l}\text { 1: Quadratic wear } \\
\text { 2: Weibull distr. }\end{array}$ \\
\hline Meier-Hirmer et al. (2005) & Markov chain & Inspection \& tamping & Gamma distr. \\
\hline Zhao et al. (2006b) & LCC & Tamping \& renewal & Exponential deterioration \\
\hline Podofillini et al. (2006) & $\begin{array}{l}\text { Multi-objective opt } \\
+ \text { Markov chain }\end{array}$ & Crack insp. \& repair & $\begin{array}{l}\text { Fixed \& exponential } \\
\text { probabilities, GA }\end{array}$ \\
\hline Lyngby et al. (2008) & Markov chain & 1: Crack insp. 2: Geom. insp. & Various distr. \& calibrations \\
\hline $\begin{array}{l}\text { Antoni (2009) and Antoni } \\
\text { and Meier-Hirmer (2008) }\end{array}$ & $\begin{array}{c}\text { Cont. statistical } \\
\text { LCC }\end{array}$ & Track, signalling, contact wire & Weibull distr. \\
\hline $\begin{array}{l}\text { Meier-Hirmer and Pouligny } \\
(2008)\end{array}$ & LCC & Grinding & $\begin{array}{l}\text { Models for rail repair, defect } \\
\text { growth \& elimination rate }\end{array}$ \\
\hline Liu et al. (2014) & $\begin{array}{l}\text { Sum of cost } \\
\text { components }\end{array}$ & Ultra-sonic inspection & Models from other references \\
\hline Gustavsson et al. (2014) & $\begin{array}{l}\text { Scheduling with } \\
\text { interval costs }\end{array}$ & Grinding & $\begin{array}{c}\text { Discrete time }=\text { traffic load. IP } \\
\text { formulation }\end{array}$ \\
\hline Chen et al. $(2013,2014)$ & $\begin{array}{l}\text { Multiobjective } \\
\text { non-linear opt }\end{array}$ & $\begin{array}{l}\text { Power supply, component and } \\
\text { substation maintenance }\end{array}$ & $\begin{array}{l}\text { GSQP, GA, TS, hybrids. } \\
\text { Weibull distr }\end{array}$ \\
\hline Dhanisetty et al. (2015) & $\begin{array}{l}\text { Fuzzy multiobjective } \\
\text { approach }\end{array}$ & Detection cable replacement & Weibull distr. \\
\hline Shang (2015) & $\begin{array}{l}\text { Maintenance policy } \\
\text { simulations }\end{array}$ & Inspections and tamping & $\begin{array}{l}\text { Colored Petri Nets, Monte } \\
\text { Carlo Simulations }\end{array}$ \\
\hline Liu and Dick (2016) & $\begin{array}{l}\text { Bi-objective opt } \\
\text { (risk and cost) }\end{array}$ & Rail defect inspection & $\begin{array}{l}\text { Hazards for crude oil } \\
\text { transportation }\end{array}$ \\
\hline
\end{tabular}

Descriptions of publications made until 2014 are given in Lidén (2014, Section 5.1.2, p 28-29).

Dhanisetty et al. (2015) consider non-repairable products that are replaced upon failure. A "fuzzy" multiobjective (cost vs reliability) approach, based on a Weibull distribution, is used. The rail case is a detection cable which "sense the oncoming train and set off the track crossing signalling system".

Shang (2015) uses Colored Petri Nets and Monte Carlo Simulations for studying different maintenance policies. A tamping case is considered where speed restrictions and repair delays are considered for a five-section line. Various outcomes, such as system throughput, maintenance cost and downtime are analysed in order to show the best selection of speed restrictions vs repair delays.

Liu and Dick (2016) study how to reduce risk of rail breakage by segmentspecific ultrasonic rail defect inspection. A bi-objective approach for risk vs cost is analysed in order to reduce the hazards regarding crude oil transportations.

\section{Network design considering maintenance - Table 3.6}

Since maintenance constitute an important part of the infrastructure properties it should be included in the network design decisions, but surprisingly few papers have been found that do so.

Descriptions of publications made until 2014 are given in Lidén (2014, Section 5.1.1, p 27).

Edwards (2015) study how transport demands can be routed through a capacitated network at minimum cost on a yearly and national level, with 
Table 3.6: References about network design approaches

\begin{tabular}{|c|c|c|c|c|c|}
\hline Reference & Model & Objective & Variables & Techniques & Data \\
\hline $\begin{array}{l}\text { Lai and } \\
\text { Barkan (2011) }\end{array}$ & $\begin{array}{c}\text { Network design, multi-comm. } \\
\text { traffic flow }\end{array}$ & $\begin{array}{l}\text { WS: Investm. }+ \\
\text { traffic flow cost }\end{array}$ & $\begin{array}{l}\text { Investm. opt.'s, } \\
\text { flow of trains }\end{array}$ & MIP & $\mathrm{RN}$ \\
\hline $\begin{array}{l}\text { Lai et al. } \\
(2013)\end{array}$ & $\begin{array}{l}\text { Multi-comm. netw. flow, track } \\
\text { class dep. speed \& maint. cost }\end{array}$ & $\begin{array}{l}\text { WS: Maint. }+ \\
\text { transp. cost }\end{array}$ & $\begin{array}{l}\text { Track class, } \\
\text { flow of trains }\end{array}$ & $\begin{array}{l}\text { MIP, Lagr. } \\
\text { relax. }\end{array}$ & $\mathrm{RN}$ \\
\hline $\begin{array}{l}\text { Edwards } \\
(2015)\end{array}$ & Transpor demand routing & $\begin{array}{l}\text { Generalized } \\
\text { transp. cost }\end{array}$ & $\begin{array}{c}\text { Route choice } \\
\text { columns }\end{array}$ & ColGen & $\mathrm{RN}$ \\
\hline
\end{tabular}

the purpose of finding correct freight cost figures in assessment studies for infrastructure investment proposals and transport planning. Although maintenance options are not directly mentioned, this type of model can be used for analysing the traffic effects of different maintenance policies. A column generation method is used where dual values from the residual capacity constraints will drive the search for alternate paths.

\section{Renewal scheduling and upgrade project planning - Table 3.7}

When considering a network with varying track quality, traffic load etc, the maintenance and renewal jobs must be jointly planned over a long time period, which this line of research considers. Several of the publications include benefits of combining projects so as to minimize the track closures and reduce work costs.

Table 3.7: References about renewal scheduling and project planning

\begin{tabular}{|c|c|c|c|c|c|}
\hline Reference & Model & Objective & Variables & Techniques & Data \\
\hline Lévi (2001) & $\begin{array}{c}\text { Multi-period } \\
\text { statistical model }\end{array}$ & Track renewal cost & $\begin{array}{l}\text { Ballast, sleeper \& } \\
\text { rail renewal }\end{array}$ & $\begin{array}{l}\text { Rule-based } \\
\text { constr. heur. }\end{array}$ & $\mathrm{RN}$ \\
\hline $\begin{array}{l}\text { Zhao et al. } \\
(2009)\end{array}$ & $\begin{array}{l}\text { Multi-period } \\
\text { scheduling }\end{array}$ & $\begin{array}{c}\text { Synchronization } \\
\text { benefit }\end{array}$ & $\begin{array}{l}\text { Ballast, sleeper \& } \\
\text { rail renewal }\end{array}$ & GA & $\begin{array}{c}\mathrm{TL} \\
10 \mathrm{y} / 1 \mathrm{y}\end{array}$ \\
\hline $\begin{array}{l}\text { Andrade and } \\
\text { Teixeira (2011) }\end{array}$ & $-"-$ & $\begin{array}{l}\text { MO: Maint. cost \& } \\
\text { Delay cost }\end{array}$ & $\begin{array}{c}\text { Tamping \& } \\
\text { renewals }\end{array}$ & $\begin{array}{l}\text { Simulated } \\
\text { annealing }\end{array}$ & $\begin{array}{c}\mathrm{TN} \\
30 \mathrm{y} / 3 \mathrm{~m}\end{array}$ \\
\hline $\begin{array}{l}\text { Caetano and } \\
\text { Teixeira (2013) }\end{array}$ & $-"$ & $\begin{array}{l}\text { MO: Unavailability } \\
\text { \& LCC }\end{array}$ & $\begin{array}{l}\text { Tamping, sleeper \& } \\
\text { rail rep. + renewal }\end{array}$ & GA & $\begin{array}{c}\mathrm{RL} \\
20 \mathrm{y} / 3 \mathrm{~m}\end{array}$ \\
\hline $\begin{array}{l}\text { Zhang et al. } \\
\text { (2013a) }\end{array}$ & $\begin{array}{l}\text { Project } \\
\text { scheduling }\end{array}$ & $\begin{array}{l}\text { Poss. time, over- or } \\
\text { underuse, robustness }\end{array}$ & Start time & $\begin{array}{c}\text { GA, } \\
\text { Petri-Net }\end{array}$ & $\begin{array}{c}\text { TN } \\
3 y / 1 d\end{array}$ \\
\hline $\begin{array}{l}\text { Caetano and } \\
\text { Teixeira (2014) }\end{array}$ & $\begin{array}{l}\text { Multi-period } \\
\text { scheduling }\end{array}$ & LCC & $\begin{array}{l}\text { Ballast, sleeper \& } \\
\text { rail renewal }\end{array}$ & MIP & $\begin{array}{c}\mathrm{RL} \\
20 \mathrm{y} / 1 \mathrm{y}\end{array}$ \\
\hline $\begin{array}{l}\text { Caetano and } \\
\text { Teixeira (2016b) }\end{array}$ & -"- & $\begin{array}{c}\text { LCC and } \\
\text { unavailability }\end{array}$ & $-"-$ & -"- & $-"-$ \\
\hline $\begin{array}{l}\text { Lethanh and } \\
\text { Adey }(2016)\end{array}$ & $\begin{array}{l}\text { Renewal } \\
\text { scheduling }\end{array}$ & Real option price & Time period & Enumeration & $\begin{array}{c}\text { TL } \\
80 / 1 \text { tu }\end{array}$ \\
\hline
\end{tabular}

Descriptions of publications made until 2014 are given in Lidén (2014, Section 5.1.3, p 29-31).

Caetano and Teixeira (2016b) is a continuation on previous publications by the same authors, where opportunistic renewal of track components are considered. 
Lethanh and Adey (2016) use real option pricing and complete enumeration for finding the optimal time period to perform renewal projects along multi-national railway lines and freight corridors.

\subsubsection{Tactical problems}

Tactical problems have been studied in more than half of the research publications. Three major lines of research have been identified, which we label as (1) Possession scheduling, (2) Deterioration-based maintenance scheduling, and (3) Maintenance vehicle routing and team scheduling. At the end of this section, some studies that concern rescheduling will be described, although they focus on trains and not on the maintenance activities.

\section{Possession scheduling - Table 3.8}

Maintenance possession scheduling is the equivalent of train timetabling and has thus attracted several research studies with somewhat various approaches and focus.

Table 3.8: References about possession scheduling

\begin{tabular}{|c|c|c|c|c|c|}
\hline Reference & Model & Objective & Variables & Techniques & Data \\
\hline Ruffing (1993) & $\begin{array}{c}\text { Timetable } \\
\text { adjustment }\end{array}$ & Min delay & $\begin{array}{c}\text { Start times, } \\
\text { departures }\end{array}$ & $\begin{array}{l}\text { Seq. constr. } \\
\text { heuristic }\end{array}$ & $\mathrm{RN}$ \\
\hline Higgins (1998) & $\begin{array}{c}\text { Crew } \leftrightarrow \text { task assign. } \\
\& \text { sched. }\end{array}$ & $\begin{array}{l}\text { WS: Interf. delay } \\
\text { \& finish time }\end{array}$ & $\begin{array}{c}\text { Assignment, start } \\
\text { times }\end{array}$ & TS & $\begin{array}{c}\mathrm{RL} \\
4 \mathrm{~d} / 1 \mathrm{~h}\end{array}$ \\
\hline $\begin{array}{l}\text { Lake et al. (2000, } \\
2002)\end{array}$ & $\begin{aligned} \text { Crew } & \leftrightarrow \text { task assign. } \\
& \& \text { sched. }\end{aligned}$ & Work cost & $\begin{array}{c}-"-+ \text { possible work } \\
\text { split }\end{array}$ & SA, TS, LS & $\begin{array}{c}\mathrm{TL} \\
1 \mathrm{w} / 1 \mathrm{~d}\end{array}$ \\
\hline $\begin{array}{l}\text { Lake and Ferreira } \\
(2002)\end{array}$ & $-"-$ & $\begin{array}{l}\text { WS: Work cost \& } \\
\text { risk of delay }\end{array}$ & -"- & -"- & $-"-$ \\
\hline $\begin{array}{l}\text { Zante-de Fokkert } \\
\text { et al. }(2007)\end{array}$ & $\begin{array}{c}\text { Poss. pattern } \leftrightarrow \\
\text { work night assign. }\end{array}$ & $\begin{array}{c}\text { HO: Maint. } \\
\text { nights, work load }\end{array}$ & Assignment & MIP & $\begin{array}{c}\mathrm{RN} \\
4 \mathrm{w} / 1 \mathrm{~d}\end{array}$ \\
\hline Budai-Balke (2009) & $\begin{array}{l}\text { Coord. prev. maint. } \\
\text { \& large projects }\end{array}$ & $\begin{array}{l}\text { Poss. and maint. } \\
\text { cost }\end{array}$ & $\begin{array}{c}\text { Task } \leftrightarrow \text { period } \\
\text { assignment }\end{array}$ & $\begin{array}{l}\text { MIP, constr. } \\
\text { heuristics, GA }\end{array}$ & $\begin{array}{c}\mathrm{TL} \\
2 \mathrm{y} / 1 \mathrm{w}\end{array}$ \\
\hline $\begin{array}{l}\text { Pouryousef et al. } \\
(2010)\end{array}$ & -"- & -"- & -"- & MIP & RL \\
\hline Jenema (2011) & $\begin{array}{l}\text { Assign prescribed } \\
\text { maint. to open slots }\end{array}$ & $\begin{array}{c}\text { Poss., maint., } \\
\text { project \& closure } \\
\text { cost }\end{array}$ & Assignment & MIP & $\begin{array}{c}\mathrm{RJ} \\
1 \mathrm{y} / 1 \mathrm{~d}\end{array}$ \\
\hline Boland et al. (2013) & $\begin{array}{l}\text { Adjust maint. } \\
\text { schedule }\end{array}$ & $\begin{array}{l}\text { Max traffic flow, } \\
\text { min adjustment }\end{array}$ & Task start times & $\begin{array}{l}\text { Netw. flow, } \\
\text { heur. reduct. }\end{array}$ & $\begin{array}{c}\mathrm{RN} \\
1 \mathrm{y} / 0.5 \mathrm{~h}\end{array}$ \\
\hline Boland et al. (2014) & -"- & -"- & -"- & $\begin{array}{l}\text { LS in max flow } \\
\text { search }\end{array}$ & $\begin{array}{c}\mathrm{RN} \\
1 \mathrm{y} / 1 \mathrm{~h}\end{array}$ \\
\hline $\begin{array}{l}\text { Albrecht (2009); } \\
\text { Albrecht et al. (2013) }\end{array}$ & $\begin{array}{l}\text { Sched. maint. poss. } \\
\& \text { adjust train plan }\end{array}$ & $\begin{array}{l}\text { Total train and } \\
\text { maint. delay }\end{array}$ & $\begin{array}{c}\text { Departures, start } \\
\text { times }\end{array}$ & $\begin{array}{l}\text { MIP, SPP, } \\
\text { B\&P, PSS }\end{array}$ & $\begin{array}{c}\mathrm{RL} \\
1 \mathrm{~d} / 1 \mathrm{~m}\end{array}$ \\
\hline Forsgren et al. (2013) & -"- & $\begin{array}{l}\text { HO: Conflicts, } \\
\text { cancellations, } \\
\text { delays }\end{array}$ & $\begin{array}{l}\text { Start times, alt. } \\
\text { routes, cancell'ns, } \\
\text { departures }\end{array}$ & $\begin{array}{l}\text { MIP w clique } \\
\text { based cuts }\end{array}$ & $\begin{array}{c}\mathrm{RN} \\
1 \mathrm{~d} / 1 \mathrm{~m}\end{array}$ \\
\hline $\begin{array}{l}\text { Pearce and Forbes } \\
(2016)\end{array}$ & $\begin{array}{l}\text { Adjust maint. } \\
\text { schedule }\end{array}$ & $\begin{array}{l}\text { Max traffic flow, } \\
\text { min adjustment }\end{array}$ & Task start times & $\begin{array}{l}\text { Benders } \\
\text { decomp. }\end{array}$ & $\begin{array}{c}\mathrm{RN} \\
1 \mathrm{y} / 0.5 \mathrm{~h}\end{array}$ \\
\hline
\end{tabular}

Descriptions of publications made until 2014 are given in Lidén (2014, Section 5.1.4, p 32-33).

Pearce and Forbes (2016) study the same problem as Boland et al. (2013). A disaggregated Benders decomposition scheme is presented, which gives 
better solution performance on the same set of test instances as used by Boland et al.

\section{Deterioration-based maintenance scheduling - Table 3.9}

The deterioration of the infrastructure components has a fundamental impact on the scheduling of maintenance vehicles and teams and several researchers have studied these problems, focusing on the deterioration predictions and/or the scheduling issues.

Table 3.9: References about deterioration-based maint. scheduling

\begin{tabular}{|c|c|c|c|c|c|}
\hline Reference & Model & Objective & Variables & Techniques & Data \\
\hline $\begin{array}{l}\text { Murakami and } \\
\text { Turnquist (1985) }\end{array}$ & $\begin{array}{l}\text { Maint. resource } \\
\text { alloc. \& sched. }\end{array}$ & $\begin{array}{l}\text { Weighted track } \\
\text { quality }\end{array}$ & $\begin{array}{c}\text { Machine } \\
\text { assignment and } \\
\text { time }\end{array}$ & $\begin{array}{l}\text { Non-linear } \\
\text { MIP, reduced } \\
\text { grad. meth. }\end{array}$ & $\begin{array}{c}\mathrm{RN} \\
3 \mathrm{y} / 3 \mathrm{~m}\end{array}$ \\
\hline Miwa (2002) & $\begin{array}{l}\text { Machine } \\
\text { scheduling }\end{array}$ & $\begin{array}{l}\text { Two-phase: } \\
\text { Tamping cost; } \\
\text { Track quality }\end{array}$ & $\begin{array}{c}\text { Depot / section } \\
\leftrightarrow \text { time } \\
\text { assignment }\end{array}$ & $\begin{array}{l}\text { MIP, seq. of } \\
\text { relaxed } \\
\text { probl's }\end{array}$ & $\begin{array}{c}\mathrm{RL} \\
6 \mathrm{~m} / 10 \mathrm{~d}\end{array}$ \\
\hline $\begin{array}{l}\text { Oyama and Miwa } \\
(2006)\end{array}$ & $\begin{array}{l}\text { Work grouping \& } \\
\text { Machine } \\
\text { scheduling }\end{array}$ & $\begin{array}{l}\text { Track quality } \\
\text { improvement }\end{array}$ & $\begin{array}{l}\text { Sect. grouping \& } \\
\text { Depot / sect. } \leftrightarrow \\
\text { time assignment }\end{array}$ & IP \& MIP & $\begin{array}{c}\mathrm{RN} \\
1 \mathrm{y} / 10 \mathrm{~d}\end{array}$ \\
\hline $\begin{array}{l}\text { Vale et al. (2010); } \\
\text { Vale et al. }(2012)\end{array}$ & $\begin{array}{c}\text { Activity } \\
\text { scheduling }\end{array}$ & Tamping actions & $\begin{array}{l}\text { Section } \leftrightarrow \text { time } \\
\text { assignment }\end{array}$ & $\begin{array}{l}\text { Linearized } \\
\text { MIP }\end{array}$ & $\begin{array}{c}\mathrm{RL} \\
2 \mathrm{y} / 3 \mathrm{~m}\end{array}$ \\
\hline Vale et al. (2011) & -"- & Tamping cost & -"- & -"- & $\begin{array}{c}\mathrm{RL} \\
5 \mathrm{y} / 3 \mathrm{~m}\end{array}$ \\
\hline Famurewa (2013) & $\begin{array}{l}\text { Machine } \\
\text { scheduling }\end{array}$ & $\begin{array}{l}\text { Machine } \\
\text { utilization }\end{array}$ & $-"-$ & Constr. heur. & $\begin{array}{c}\mathrm{RL} \\
2 \mathrm{y} / 1 \mathrm{~d}\end{array}$ \\
\hline $\begin{array}{l}\text { Quiroga et al. } \\
\text { (2011) }\end{array}$ & $\begin{array}{l}\text { Maintenance } \\
\text { scheduling }\end{array}$ & Track quality & $\begin{array}{l}\text { Start. \& ending } \\
\text { depot / section }\end{array}$ & Constr. heur. & RL \\
\hline $\begin{array}{l}\text { Gustavsson } \\
(2015)\end{array}$ & $\begin{array}{l}\text { Activity } \\
\text { scheduling }\end{array}$ & $\begin{array}{l}\text { Tamping cost }+ \\
\text { traffic impact }\end{array}$ & $\begin{array}{l}\text { Section } \leftrightarrow \text { time } \\
\text { assignment }\end{array}$ & IP & $\begin{array}{c}\mathrm{TL} \\
2 \mathrm{y} / 2 \mathrm{w}\end{array}$ \\
\hline $\begin{array}{l}\text { Li et al. (2015); } \\
\text { Wen et al. (2015) }\end{array}$ & -"- & Net present cost & -"- & MIP & $\begin{array}{c}\mathrm{RL} \\
3.5 \mathrm{y} / 3 \mathrm{~m}\end{array}$ \\
\hline $\begin{array}{l}\text { Caetano and } \\
\text { Teixeira (2016a) }\end{array}$ & $\begin{array}{l}\text { Maintenance } \\
\text { scheduling }\end{array}$ & $\begin{array}{l}\text { MO: cost vs } \\
\text { reliability }\end{array}$ & $-"$ & GA & RL \\
\hline
\end{tabular}

Descriptions of publications made until 2014 are given in Lidén (2014, Section 5.1.5, p 34).

Gustavsson (2015) extends the model proposed in Vale et al. (2012) by including economic dependencies in the objective function and stronger constraint formulations which decreases the computational time. A deterministic deterioration model is used and the problem is shown to be NP-hard.

Li et al. (2015) and Wen et al. (2015) also extends the work in Vale et al. (2012) by considering several economic and technical factors in the objective function. A linearised deterioration model is used and the subsequent recovery levels are controlled with a set of constraints.

Caetano and Teixeira (2016a) also studies ballast tamping, but propose a degradation model that considers uncertainties in the forecast by defining a track geometry reliability parameter. A multi-objective approach is used for considering the cost-reliability trade off, which is solved with a genetic algorithm. 


\section{Maintenance vehicle routing and team scheduling - Table 3.10}

When the maintenance jobs are known, they should be scheduled on a set of maintenance vehicles / teams with given capabilities, equipment and home locations. In this line of research the objective is to get good routings/schedules for the maintenance resources such that the total cost is minimized. Traffic considerations can be handled by imposing (soft) constraints on which jobs that can be done simultaneously.

Table 3.10: References about maint. vehicle routing \& team sched.

\begin{tabular}{|c|c|c|c|c|c|}
\hline Reference & Model & Objective & Variables & Techniques & Data \\
\hline $\begin{array}{l}\text { Gorman and } \\
\text { Kanet }(2010)\end{array}$ & $\begin{array}{l}\text { Maint. veh. routing } \\
\text { and team sched. }\end{array}$ & Total team cost & $\begin{array}{c}\text { Team and time } \leftrightarrow \\
\text { task assignment }\end{array}$ & TSN, CP, GA & $\begin{array}{c}\mathrm{TN} \\
1 \mathrm{y} / 1 \mathrm{w}\end{array}$ \\
\hline $\begin{array}{l}\text { Nemani et al. } \\
(2010)\end{array}$ & -"- & $\begin{array}{l}\text { Work cost }+ \\
\text { constr. viol. }\end{array}$ & $\begin{array}{l}-"-, \text { track closure, } \\
\text { constr. viol. }\end{array}$ & $\begin{array}{l}\text { TSN, SPP, CG, } \\
\text { decomp. heur. }\end{array}$ & $\begin{array}{c}\mathrm{RN} \\
1 \mathrm{y} / 1 \mathrm{w}\end{array}$ \\
\hline Boğ et al. (2011) & -"- & $\begin{array}{l}\text { Track closures + } \\
\text { constr. viol. }\end{array}$ & -"- & $\begin{array}{l}\text { MIP, seq. of } \\
\text { heur. reduct. }\end{array}$ & $\begin{array}{c}\mathrm{RN} \\
1 \mathrm{y} / 1 \mathrm{w}\end{array}$ \\
\hline $\begin{array}{l}\text { Peng (2011) and } \\
\text { Peng et al. } \\
(2011)\end{array}$ & -"- & $\begin{array}{l}\text { WS: Travel cost }+ \\
\text { constr. viol. }\end{array}$ & $\begin{array}{l}\text { Travel and work } \\
\text { (arc) assignment, } \\
\text { constr. viol. }\end{array}$ & $\begin{array}{l}\text { TSN, iterative } \\
\text { heuristic }\end{array}$ & $\begin{array}{c}\mathrm{RN} \\
1 \mathrm{y} / 1 \mathrm{w}\end{array}$ \\
\hline $\begin{array}{l}\text { Peng and } \\
\text { Ouyang (2012) }\end{array}$ & $-"$ & $-"$ & $-"-$ & $\begin{array}{c}\text { TSN, decomp., } \\
\text { LNS }\end{array}$ & $\begin{array}{c}\mathrm{RN} \\
1 \mathrm{y} / 1 \mathrm{w}\end{array}$ \\
\hline $\begin{array}{l}\text { Borraz-Sánchez } \\
\text { and Klabjan } \\
(2012)\end{array}$ & -"- & -"- & -"- & $\begin{array}{c}\text { Job-time netw., } \\
\text { DP+LS, } \\
\text { LNS+IP }\end{array}$ & $\begin{array}{l}\mathrm{RN} \\
1 \mathrm{y} / 1 \mathrm{~d}\end{array}$ \\
\hline $\begin{array}{l}\text { AUTOMAIN } \\
(2013)\end{array}$ & $\begin{array}{l}\text { Job combination; } \\
\text { Path finding; } \\
\text { Movement sched. }\end{array}$ & $\begin{array}{l}\text { Poss. time, target } \\
\text { dates, mach. } \\
\text { usage, delays }\end{array}$ & $\begin{array}{c}\text { Task time, } \\
\text { movement path \& } \\
\text { time, train adjustm. }\end{array}$ & $\begin{array}{c}\text { LS, SA; } \\
\text { shortest path; } \\
\text { MIP }\end{array}$ & $\begin{array}{l}\text { RN 1- } \\
3 y / 1 w- \\
1 \mathrm{~h}\end{array}$ \\
\hline $\begin{array}{l}\text { Peng and } \\
\text { Ouyang (2014) }\end{array}$ & $\begin{array}{l}\text { Clustering jobs into } \\
\text { projects }\end{array}$ & $\begin{array}{l}\text { Project duration } \\
+ \text { constr. viol. }\end{array}$ & $\begin{array}{l}\text { Travel and work } \\
\text { (arc) assignment, } \\
\text { constr. viol. }\end{array}$ & $\begin{array}{c}\text { Constr. } \\
\text { heuristic + LNS }\end{array}$ & $\begin{array}{c}\mathrm{RN} \\
1 \mathrm{y} / 1 \mathrm{w}\end{array}$ \\
\hline $\begin{array}{l}\text { Lannez et al. } \\
(2015)\end{array}$ & $\begin{array}{l}\text { Track inspection } \\
\text { scheduling }\end{array}$ & $\begin{array}{c}\text { Completion rate } \\
\text { and deadhead } \\
\text { distance }\end{array}$ & $\begin{array}{l}\text { Shift patterns, task } \\
\text { and travel times }\end{array}$ & $\begin{array}{c}\text { TSN, CG, } \\
\text { Benders } \\
\text { decomp, heur. }\end{array}$ & $\begin{array}{l}\mathrm{RN} \\
1 \mathrm{y} / \mathrm{c}\end{array}$ \\
\hline $\begin{array}{l}\text { Mohammad } \\
\text { Pour et al. } \\
(2015 \mathrm{a}, \mathrm{b})\end{array}$ & $\begin{array}{l}\text { Inspection tour } \\
\text { construction }\end{array}$ & $\begin{array}{c}\text { Transportation } \\
\text { time }\end{array}$ & $\begin{array}{l}\text { Route choice and } \\
\text { schedule time }\end{array}$ & $\begin{array}{c}\text { Clustering }+ \\
\text { constr. } \\
\text { heuristic }\end{array}$ & $\mathrm{TN}$ \\
\hline Camci (2015) & $\begin{array}{l}\text { Maint. scheduling } \\
\text { and team routing }\end{array}$ & $\begin{array}{l}\text { Failure, maint. } \\
\text { and travel cost }\end{array}$ & $\begin{array}{l}\text { Maint. time and } \\
\text { ordering }\end{array}$ & GA & $\begin{array}{c}\mathrm{TN} \\
9 \mathrm{w} / 1 \mathrm{~d}\end{array}$ \\
\hline $\begin{array}{l}\text { Santos et al. } \\
(2015)\end{array}$ & Maint. veh. routing & $\begin{array}{l}\text { Travel, work and } \\
\text { anticipation cost }\end{array}$ & $\begin{array}{c}\text { Tamping schedule } \\
\text { time }\end{array}$ & $\begin{array}{l}\text { Rule based } \\
\text { constr. } \\
\text { heuristic }\end{array}$ & $\begin{array}{c}\mathrm{RL} \\
5 \mathrm{y} / 1 \mathrm{~d}\end{array}$ \\
\hline
\end{tabular}

Legends: $\mathrm{WS}=$ weighted sum; TSN $=$ time-space network; $\mathrm{CP}=$ constraint programming; GA $=$ genetic algorithm; SPP = set partitioning problem; CG = column generation; $\mathrm{MIP}=$ mixed integer linear program $\mathrm{DP}=$ dynamic programming; $\mathrm{LS}=$ local search; LNS = large neighborhood search; IP = integer program; RN = real data for a network.

Descriptions of publications made until 2014 are given in Lidén (2014, Section 5.1.6, p 36-37).

Lannez et al. (2015), based on the PhD thesis Lannez (2010), study the scheduling of track inspections applied to vehicles for ultrasonic testing. The modelling considers vehicle capabilities, refill locations and track outages. The problem is classified as "multicapacitated arc routing [..] with time windows, refill points and a heterogeneous fleet", which should be solved for the yearly scheduling on the main lines of the French national network. A so called matheuristic approach, based on Benders decomposition, divided into 4 steps is presented and tested on real life data instances. Comparisons are also made with a dynamic programming approach.

Mohammad Pour et al. (2015a,b) considers the planning of inspection 
tours for a new signalling system (ERTMS) in Denmark. A two-step solution process is employed that clusters the jobs and then solves a multi-depot crew routing problem with time windows and synchronisation constraints for nodes that requires shared visits.

Camci (2015) study how to schedule maintenance of geographically distributed assets for a maintenance team which should return to a depot. Several cost factors, schedule constraints and degradation prognostics are considered in a model which is solved with a genetic algorithm approach.

Santos et al. (2015) use a rule-based model for scheduling maintenance teams that perform tamping and stabilisation work during night time with little interaction with the traffic. The heuristic approach is compared with exact optimization models.

\section{Rescheduling}

Rescheduling of maintenance might be triggered by changes in budgets, train paths etc. No literature references have been found that treat this subject. There is however some work done regarding the opposite problem of replanning a timetable or operative train plan due to track closures (complete or partial) or maintenance activities, for example in: Brucker et al. (2005) (scheduling of single track traffic past a working site on a line section); Vansteenwegen et al. (2015) (robust rescheduling due to planned track closures on large stations and junctions); and Louwerse and Huisman (2014) and Veelenturf et al. (2015) (rescheduling of timetables, rolling stock and crew during major disruptions in operational dispatching). In all these cases the track closures / maintenance are given as fixed input.

\subsubsection{Operational problems and other aspects}

Relatively few publications have been found regarding operational planning problems. One line of research has been identified and labelled as "Work timing and resource scheduling". In addition, the aspect of "Scenario planning" will finally be discussed briefly.

\section{Work timing and resource scheduling - Table 3.11}

This line of research considers the detailed planning and scheduling of maintenance tasks and resources. A large number of inspections as well as rectification tasks shall be efficiently scheduled. Some activities may be deferred as long as the risk levels are within acceptable limits.

Descriptions of publications made until 2014 are given in Lidén (2014, p 32 (Cheung) and Section 5.1.7, p 39-40).

Baldi et al. (2015) study the planning of rectification scheduling when the future conditions and inspection remarks are stochastic. An adaptive scheduling is done for a rolling horizon and tested with various heuristic solution techniques, including GRASP and GA. 
Table 3.11: References about work timing and resource scheduling

\begin{tabular}{|c|c|c|c|c|c|}
\hline Reference & Model & Objective & Variables & Techniques & Data \\
\hline $\begin{array}{l}\text { Cheung et al. } \\
\text { (1999) }\end{array}$ & Job scheduling & Max work & $\begin{array}{c}\text { Job } \leftrightarrow \text { night } \\
\text { assign. }\end{array}$ & $\begin{array}{l}\mathrm{CP}, \text { priority } \\
\text { rules }\end{array}$ & $\begin{array}{c}\mathrm{RN} \\
1 \mathrm{w} / 1 \mathrm{~d}\end{array}$ \\
\hline $\begin{array}{l}\text { Zhao et al. } \\
\text { (2006a) }\end{array}$ & $\begin{array}{l}\text { k-out-of-n consec. } \\
\text { comp. repair }\end{array}$ & $\begin{array}{l}\text { Sum of immediate } \\
\text { repairs }\end{array}$ & Unit selection & $\begin{array}{l}\text { Non-linear IP, } \\
\text { steepest } \\
\text { gradient }\end{array}$ & small TL \\
\hline $\begin{array}{l}\text { Peng et al. } \\
\text { (2013) }\end{array}$ & $\begin{array}{l}\text { Scheduling } \\
\text { periodic } \\
\text { inspections }\end{array}$ & $\begin{array}{l}\text { Periodicity variance } \\
+ \text { constr. viol. }\end{array}$ & $\begin{array}{l}\text { Travel and work } \\
\text { (arc) assignment, } \\
\text { constr. viol. }\end{array}$ & $\begin{array}{l}\text { VRP, increasing } \\
\text { horizon + LNS }\end{array}$ & $\begin{array}{c}\mathrm{RN} \\
8 \mathrm{w} / \mathrm{c} \text { or } \\
1 \mathrm{y} / \mathrm{c}\end{array}$ \\
\hline $\begin{array}{l}\text { Zhang et al. } \\
\text { (2013b) }\end{array}$ & $\begin{array}{l}\text { Condition-based } \\
\text { maintenance } \\
\text { scheduling }\end{array}$ & $\begin{array}{l}\text { Unsafe operation, } \\
\text { unused comp. life, } \\
\text { maint. \& travel cost }\end{array}$ & $\begin{array}{l}\text { Team \& date } \leftrightarrow \\
\text { task assignment }\end{array}$ & GA & $\begin{array}{l}\mathrm{RN} \\
1 \mathrm{~m} / 1 \mathrm{~d}\end{array}$ \\
\hline $\begin{array}{l}\text { He et al. } \\
(2014)\end{array}$ & $\begin{array}{l}\text { Scheduling defect } \\
\text { rectification }\end{array}$ & $\begin{array}{c}\text { Total cost or risk of } \\
\text { derailment }\end{array}$ & $\begin{array}{l}\text { Task and time } \\
\text { selection }\end{array}$ & MIP & $\begin{array}{c}\mathrm{RN} \\
1 \mathrm{~m} / 1 \mathrm{~d}\end{array}$ \\
\hline $\begin{array}{l}\text { Heinicke } \\
\text { et al. }(2014)\end{array}$ & $\begin{array}{l}\text { Routing } \\
\text { corrective } \\
\text { tamping }\end{array}$ & $\begin{array}{l}\text { Travel cost }+ \text { service } \\
\text { limit penalty }\end{array}$ & $\begin{array}{l}\text { Travel / work } \\
\text { assignment }\end{array}$ & $\begin{array}{l}\text { Linearized MIP, } \\
\text { relaxation + } \\
\text { subtour elim. }\end{array}$ & $\begin{array}{c}\mathrm{TN} \\
\mathrm{xw} / 1 \mathrm{~m}\end{array}$ \\
\hline $\begin{array}{l}\text { Baldi et al. } \\
(2015)\end{array}$ & $\begin{array}{l}\text { Rectification } \\
\text { scheduling }\end{array}$ & $\begin{array}{l}\text { Work allocation and } \\
\text { penalty cost }\end{array}$ & $\begin{array}{l}\text { Task time } \\
\text { assignment }\end{array}$ & $\begin{array}{c}\text { Heur., GRASP, } \\
\text { GA }\end{array}$ & $\begin{array}{c}\mathrm{TN} \\
36 \mathrm{~m} / 1 \mathrm{~d}\end{array}$ \\
\hline
\end{tabular}

\section{Scenario planning}

Scenario planning have been suggested as a method for anticipating future problems and preparing recovery or reduction plans. No publications have been found regarding maintenance planning but Azad et al. (2016) presents an analysis method and a set of optimization models for pre- and postdisruption handling of train traffic. Sensitive links and services are identified from which mitigation strategies are developed.

\subsection{Concluding remarks}

This chapter has given a broad overview of the research state regarding optimization methods for solving railway maintenance planning problems. Although the number of publications are steadily increasing, there are still many problems that have not yet been treated.

The planning problem addressed in Paper 2 and 3 of this thesis belongs to Possession scheduling. Even though several publications exists in this area, very few treat the concurrent scheduling of maintenance and train services and none have been found that study the long-term tactical planning case. 



\section{Chapter 4}

\section{Research results}

This chapter contains a summary of the results in Papers 1-3, where the first is a survey of planning problems and conducted research, the second concerns the dimensioning of maintenance windows by assessing costs and benefits for maintenance as well as train traffic, and the third describes an optimization model for joint scheduling of both maintenance windows and train services.

\subsection{Survey of planning problems and con- ducted research}

Paper 1 gives a comprehensive overview of the railway infrastructure maintenance field, the planning problems it contains and the research that had been conducted until 2014. Based on a series of interviews with experts and planners, representing all major stake holders, a catalogue of planning problems is presented with focus on infrastructure maintenance and the coordination with train traffic. The paper also contains a literature overview covering about 60 research references regarding the use of mathematical methods and optimization for solving such planning problems. Finally, some statistics and a mapping is presented which identifies the problem areas that had been addressed at that time in the literature as well as future research possibilities.

The literature overview and research statistics in Paper 1 is superseded by the literature survey presented in Chapter 3, which provides more details and covers publications until April 2016. 


\subsection{Assessment of costs and benefits}

Paper 2 addresses the issue of how to establish quantitative measures for comparing conflicting capacity needs from infrastructure maintenance and traffic operations on railway networks. A model is presented, consisting of three parts, which calculates (1) changes in maintenance cost, (2) adjustment costs for freight traffic, and (3) changes in passenger traffic and travel demand, when introducing maintenance windows of varying size. The model is demonstrated on a real life case study concerning the Swedish Northern Main Line.

The main contribution of the paper is the sub-model for the maintenance part - consisting of analytical equations for calculating the change in cost depending on the available train free time. It is shown that the maintenance time is inversely proportional to the window size $t^{w}$. Figure 4.1 illustrates this by showing the normalized time difference $d \hat{T}$ versus the normalized window size $\hat{t}=t^{w} / w$ for a job type with task time $w$ and various settings of the overhead (setup) time $u^{i}$ performed during (inside) the possession time. As seen, the maintenance time (and thereby cost) quickly rises when the window size is reduced.

Figure 4.1: Relative time difference vs window size for different overhead settings. All values are normalized - time difference by the total nominal overhead, window size $\left(\hat{t}=t^{w} / w\right)$ and overhead $(\hat{u}=$ $\left.u^{i} / w\right)$ by the task time $(w)$.

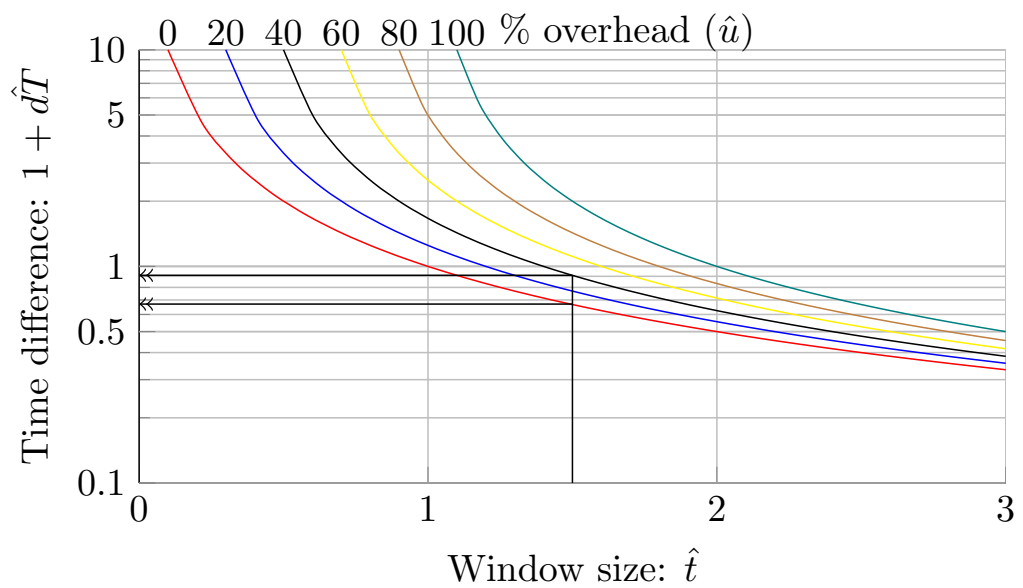

The diagram can be used for finding break-even window sizes as well as changes in work time for different settings. As an example (shown in the figure) a window size of $t^{w}=1.5 w$ will reduce the total maintenance time to 0.67 when all overhead is done outside of the possession $(\hat{u}=0)$. If the overhead time is $40 \%$ of the task time, i.e. $u^{i}=0.4 w$, the reduction is merely 0.9 . 
The sub-model for freight traffic considers the change in operator costs, when train services need to be adjusted or possibly rejected due to the maintenance windows. A homogeneous and symmetric traffic case for single track lines is studied, which estimates the runtime differences as a function of the number of opposing trains and line capacity usage.

The sub-model for passenger traffic is based on existing methods from transport economics which consider the detailed travel demand, alternate transport modes and how the travel patterns will change when train services are modified due to the introduction of maintenance windows. As a consequence of changes in perceived passenger cost, the travel demand will also change, from which a net effect can be calculated both for the customers (consumer surplus) and operators (producer surplus).

The paper finally shows how to apply the costing models in a real life case study, concerning the Swedish Northern Main Line. In this specific case it is beneficial to introduce a daily $2 \mathrm{~h}$ maintenance window, given the limited amount of trains that are affected and that bus replacements are offered.

\subsection{Optimal scheduling of railway traffic and maintenance windows}

Paper 3 presents an optimization model for solving the integrated railway traffic and network maintenance scheduling problem. The aim is to produce long term tactical plans that optimally schedule train free maintenance windows together with a set of train services. The intended use case is when an infrastructure manager wants to find a pattern of maintenance windows to be used during a multi-year period as a method for assuring stable planning conditions for both maintenance contractors and train operators. The model can however be used in any situation where train services and time slots for infrastructure maintenance should be coordinated.

The problem is modelled as a mixed integer programming problem (MIP), which uses a spatial and temporal aggregation for controlling the available network capacity. In this way, larger networks and longer planning horizons become manageable. The problem size is shown to grow linearly with the planning horizon if the train scheduling windows are limited. Computational experiments on a set of synthetic test instances with about 40-50 trains per day show that a commercial MIP solver (Gurobi) can find near optimal solutions to weekly network and double track problems (where trains can pass a working site) within $1 \mathrm{~h}$ on a laptop computer. If train traffic is completely stopped by the maintenance tasks (as for single track lines) the problems are harder to solve and the largest such instances solved to within optimality in $1 \mathrm{~h}$ of computation are 1-2 days long.

The effect of reducing the train scheduling windows is studied and it is shown that tight windows can be used for the network instances, while larger 
scheduling flexibility is needed for the line instances. Some other problem reductions are also analysed, which can be beneficial in some cases but does not give any profound effect on solution performance.

The paper discusses aspects that make the problem hard to solve, some of which are due to the instance data and some that are due to the mathematical properties of the model. Data instances that (i) are close to the capacity limits, (ii) require cancellations to be considered or (iii) have little cost guidance between structurally different solutions are more complicated to solve. As for the numerical properties, the linear relaxation of the problem is weak which can be seen when studying the development of the linear bounds during the solution process and the difficulty of closing the optimality gap. The underlying reasons are attributed to unreliable fractional train counting over the time periods. Methods for improving the linear bounds and strengthening the model are therefore interesting research continuations. 


\section{Chapter 5}

\section{Conclusions and future research}

This thesis shows that the planning of railway infrastructure maintenance is an important field of study, which provides many interesting and challenging planning problems. The application of mathematical optimization methods is so far limited, especially compared to its usage in train operations and timetabling, despite the fact that the monetary volumes regarding maintenance and renewals are in the order of 40-60\% of train operations. In particular, the coordination between train traffic and railway maintenance is an increasingly important area that has received very little research focus.

Apart from collecting and structuring reference material about the maintenance activities, the major planning problems, railway practices, processes and relevant research literature, it has been shown that:

- Railway maintenance and train traffic can be quantitatively compared.

- Maintenance possessions and train services can be jointly scheduled on a tactical level with the use of optimization models.

The current work has focused on the temporal size of maintenance windows, with limited consideration to the geographical dimension and resource constraints. These aspects should be studied in future research and is needed together with the main resource considerations regarding train operations in order to achieve a strong and faithful optimization model for concurrent planning of maintenance and train services. Improvements regarding solving performance should also be studied, especially when including more and complicating (resource and functional) aspects. The application to other planning steps (strategic as well as short-term planning) could be of interest, including the detailed conflict resolution (meet/pass) planning - possibly by integration with timetable construction. 
Paper 3 discusses other functional developments for the optimization model. On a more general level, it could be of interest to use other objective functions, including multi-objective approaches and of course to evaluate and use the models on real life instances, comparative studies etc.

Some other future research directions may include methods for distributing railway maintenance efforts based on network sensitivity and transportation reliability as well as the generalization of the Integrated Service Network and Maintenance Design problem. 


\section{Bibliography}

Albrecht, A. R., Panton, D. M., and Lee, D. H. (2013). "Rescheduling rail networks with maintenance disruptions using Problem Space Search". In: Computers 83 Operations Research. Transport Scheduling 40.3, pp. 703712. DOI: $10.1016 / j$.cor .2010 .09 .001 .

Albrecht, A. (2009). "Integrating railway track maintenance and train timetables". PhD thesis. Adelaide: University of South Australia. URL: https : / / oatd . org/oatd/record? record=oai \\%3Aura . unisa . edu . au $\%$ 3Aunisa37507 (visited on 08/13/2014).

Alexandersson, G. (2015). Koll på anläggningen. Swedish. Delbetänkande SOU 2015:42, p. 230. URL: http: // www . sou . gov . se/wp-content/ uploads/2015/04/SOU-2015_421.pdf.

Andrade, A. and Teixeira, P. (2011). "Biobjective Optimization Model for Maintenance and Renewal Decisions Related to Rail Track Geometry". In: Transportation Research Record: Journal of the Transportation Research Board 2261.-1, pp. 163-170. DOI: 10.3141/2261-19.

Antoni, M. (2009). "The ageing of signalling equipment and the impact on maintenance strategy". In: International Conference on Computers Industrial Engineering, 2009. CIE 2009, pp. 1179-1184. DOI: 10.1109/ ICCIE. 2009.5223965.

Antoni, M. and Meier-Hirmer, C. (2008). "Economic correlation between maintenance and regeneration-optimisation of maintenance strategies for tracks, signalling equipment and overhead line components". In: Proceedings of the WCRR. URL: http://www.railway-research.org/IMG/ $\mathrm{pdf} / \mathrm{i} .2 .1 .4 .3 . p d f$ (visited on 06/25/2014).

AUTOMAIN (2013). D5.1 - Planning and scheduling tool for optimised maintenance. Tech. rep. D5.1. URL: http: // automain . eu/IMG/pdf / wp5_d5_1_def.pdf (visited on 08/13/2014).

Azad, N., Hassini, E., and Verma, M. (2016). "Disruption risk management in railroad networks: An optimization-based methodology and a case 
study". In: Transportation Research Part B: Methodological 85, pp. 7088. DOI: $10.1016 /$ j.trb.2016.01.001.

Baldi, M. M., Tadei, R., Heinicke, F., and Simroth, A. (2015). "New Heuristics for the Stochastic Tactical Railway Maintenance Problem". In: Omega. DOI: $10.1016 /$ j.omega.2015.10.005.

Boğ, S., Nemani, A. K., and Ahuja, R. K. (2011). "Iterative algorithms for the curfew planning problem". In: Journal of the Operational Research Society 62.4, pp. 593-607. DOI: 10.1057/jors.2010.1.

Boland, N., Kalinowski, T., Waterer, H., and Zheng, L. (2013). "Mixed integer programming based maintenance scheduling for the Hunter Valley coal chain". In: Journal of Scheduling 16.6, pp. 649-659. DOI: 10.1007/ s10951-012-0284-y.

Boland, N., Kalinowski, T., Waterer, H., and Zheng, L. (2014). "Scheduling arc maintenance jobs in a network to maximize total flow over time". In: Discrete Applied Mathematics. Matheuristics 2010 163, Part 1, pp. 3452. DOI: $10.1016 / \mathrm{j}$.dam.2012.05.027.

Borraz-Sánchez, C. and Klabjan, D. (2012). Strategic Gang Scheduling for Railroad Maintenance. CCITT, Center for the Commercialization of Innovative Transportation Technology, Northwestern University. URL: http : / / ntl . bts . gov / lib / 46000 / 46100 / 46128 / CCITT_Final_ Report_Y201.pdf (visited on 06/02/2014).

Brucker, P., Heitmann, S., and Knust, S. (2005). "Scheduling railway traffic at a construction site". In: Container Terminals and Automated Transport Systems. Ed. by P. D. H.-O. Günther and P. K. H. Kim. Springer Berlin Heidelberg, pp. 345-356. ISBN: 978-3-540-22328-3 9783-540-26686-0. DOI: 10.1007/3-540-26686-0_15.

Budai-Balke, G. (2009). "Operations research models for scheduling railway infrastructure maintenance". PhD thesis. Erasmus University, Rotterdam. ISBN: 9789036101264 9036101263. URL: http: / / repub . eur . $\mathrm{nl} / \mathrm{pub} / 16008 /$ thesis_GabriellaBudaiBalke_TI456.pdf (visited on $09 / 26 / 2013)$.

Caetano, L. and Teixeira, P. (2013). "Availability Approach to Optimizing Railway Track Renewal Operations". In: Journal of Transportation Engineering 139.9, pp. 941-948. DOI: 10.1061/(ASCE) TE . 1943-5436 . 0000575 .

Caetano, L. and Teixeira, P. (2014). "Optimisation model to schedule railway track renewal operations: a life-cycle cost approach". In: Structure and Infrastructure Engineering 11.11, pp. 1524-1536. DOI: 10.1080 / 15732479.2014.982133. 
Caetano, L. and Teixeira, P. (2016a). "Predictive Maintenance Model for Ballast Tamping". In: Journal of Transportation Engineering 142.4, p. 04016006. DOI: 10.1061/(ASCE) TE. 1943-5436.0000825.

Caetano, L. F. and Teixeira, P. F. (2016b). "Strategic Model to Optimize Railway-Track Renewal Operations at a Network Level". In: Journal of Infrastructure Systems 2016, p. 04016002. DOI: 10 . 1061/ (ASCE) IS . 1943-555X.0000292.

Camci, F. (2015). "Maintenance Scheduling of Geographically Distributed Assets with Prognostics Information". In: European Journal of Operational Research 245/2015.2, pp. 506 -516. DOI: 10.1016/j.ejor. 2015. 03.023.

Chen, S., Ho, T., and Mao, B. (2013). "Maintenance schedule optimisation for a railway power supply system". In: International Journal of Production Research 51.16, pp. 4896-4910. DOI: 10.1080/00207543.2013. 774501 .

Chen, S., Ho, T., Mao, B., and Bai, Y. (2014). "A bi-objective maintenance scheduling for power feeding substations in electrified railways". In: Transportation Research Part C: Emerging Technologies 44, pp. 350362. DOI: $10.1016 / \mathrm{j}$.trc.2014.04.016.

Cheung, B. S. N., Chow, K. P., Hui, L. C. K., and Yong, A. M. K. (1999). "Railway track possession assignment using constraint satisfaction". In: Engineering Applications of Artificial Intelligence 12.5, pp. 599-611. DOI: 10.1016/S0952-1976(99)00025-1.

Dhanisetty, V. V., Verhagen, W. J. C., and Curran, R. (2015). "Optimising maintenance intervals for multiple maintenance policies: a crossindustrial study". In: International Journal of Agile Systems and Management 8.3, pp. 219-242. DOI: 10.1504/IJASM. 2015.073519.

Edwards, H. (2015). Railway capacity management for SamGods using Linear Programming. Sweco: 7000 235. URL: http://www . trafikverket . se / contentassets / 93a250f c470d426998f0a496fea3787a / railway _ capacity_management_for_samgods_using_linnear_programming. pdf.

EIM-EFRTC-CER Working Group (2012). Market Strategies for Track Maintenance \& Renewal. Tech. rep. 2353 7473-11. CER - Community of European Railway and Infrastructure Companies. URL: http://www . cer . be/publications / brochures-studies-and-reports/reporteim-efrtc-cer-working-group-market-strategies (visited on 05/13/2016).

European Commission (2012). EU transport in figures - Statistical pocketbook 2012. Tech. rep. MI-AA-12-001-EN-C. EU, p. 132. DOI: 10.2832/52252. 
Famurewa, S., Juntti, U., and Kumar, U. (2012). "Performance based railway infrastructure maintenance: Towards achieving maintenance objectives". In: MPMM 2011 - Maintenance Performance Measurement \& Management. http://pure.ltu.se/portal. Luleå University of Technology, pp. 233-240. ISBN: 978-91-7439-379-8.

Famurewa, S. M. (2013). "Increased railway infrastructure capacity through improved maintenance practices". http://pure.ltu.se/portal/. Licentiate thesis. Luleå tekniska universitet. ISBN: 978-91-7439-545-7.

Forsgren, M., Aronsson, M., and Gestrelius, S. (2013). "Maintaining tracks and traffic flow at the same time". In: Journal of Rail Transport Planning 85 Management. Robust Rescheduling and Capacity Use 3.3, pp. 111-123. DOI: $10.1016 / j \cdot j r t p m .2013 .11 .001$.

Gorman, M. F. and Kanet, J. J. (2010). "Formulation and Solution Approaches to the Rail Maintenance Production Gang Scheduling Problem". In: Journal of Transportation Engineering 136.8, pp. 701-708. DOI: 10.1061/ (ASCE) 0733-947X (2010) 136:8(701).

Gustavsson, E. (2015). "Scheduling tamping operations on railway tracks using mixed integer linear programming". In: EURO Journal on Transportation and Logistics 4.1, pp. 97-112. DOI: 10 . 1007 /s13676-0140067-z.

Gustavsson, E., Patriksson, M., Strömberg, A.-B., Wojciechowski, A., and Önnheim, M. (2014). "Preventive maintenance scheduling of multicomponent systems with interval costs". In: Computers $\&$ Industrial Engineering 76, pp. 390-400. DOI: 10.1016/j.cie.2014.02.009.

He, Q., Li, H., Bhattacharjya, D., Parikh, D. P., and Hampapur, A. (2014). "Track geometry defect rectification based on track deterioration modelling and derailment risk assessment". In: Journal of the Operational Research Society 66, pp. 392-404. DOI: 10.1057/jors.2014.7.

Heinicke, F., Simroth, A., Scheithauer, G., and Fischer, A. (2014). On a Railway Maintenance Scheduling Problem with Customer Costs and MultiDepots. Tech. rep. MATH-NM-01-2014. Dresden, Germany: TU-Dresden. URL: http://citeseerx.ist.psu.edu/viewdoc/download?doi=10.1. 1.447.4286\&rep=rep1\&type $=p d f$ (visited on 10/02/2014).

Higgins, A. (1998). "Scheduling of Railway Track Maintenance Activities and Crews". In: The Journal of the Operational Research Society 49.10, pp. 1026-1033. DOI: 10.2307/3010526.

IATE. Inter-active Terminology for Europe. URL: http://iate . europa . eu / iatediff / SearchByQueryLoad . do ? method = load (visited on 09/26/2013). 
Jenema, A. R. (2011). "An optimization model for a Train-Free-Period planning for ProRail based on the maintenance needs of the Dutch railway infrastructure". Master thesis. Delft University of Technology. URL: http: / / repository . tudelft . nl / assets / uuid : 06252984-bcfd-49a59416-69b948bcc0ff/Scriptie.pdf (visited on 08/14/2014).

Lai, Y.-C., Dingler, M., Lin, S.-Y., and Liu, K.-C. (2013). "Optimal track class assignment for a railroad network". In: Journal of the Operational Research Society 64.12, pp. 1800-1809. DOI: 10.1057/jors.2012.159.

Lai, Y.-C. and Barkan, C. P. L. (2011). "Comprehensive Decision Support Framework for Strategic Railway Capacity Planning". In: Journal of Transportation Engineering 137.10, pp. 738-749. DOI: 10.1061/(ASCE) TE. 1943-5436.0000248.

Lake, M. and Ferreira, L. J. (2002). "Minimising the conflict between rail operations and infrastructure maintenance". In: Transportation and traffic theory. Transportation and traffic theory 15. Ed. by M. a. P. Taylor, pp. 63-74.

Lake, M., Ferreira, L., and Murray, M. (2000). "Minimising costs in scheduling railway track maintenance". In: Seventh International Conference on Computers in Railways. Vol. VII. WIT Press, pp. 895-902. ISBN: 1853128260.

Lake, M., Ferreira, L., and Kozan, E. (2002). "Heuristic Techniques for Scheduling Railway Track Maintenance". In: International series in Operations Research and Management Science. Operations Research/Management Science at work 43. Ed. by E. Kozan and A. Ohuchi, pp. $177-188$.

Lamson, S. T., Hastings, N. A. J., and Willis, R. J. (1983). "Minimum Cost Maintenance in Heavy Haul Rail Track". In: The Journal of the Operational Research Society 34.3, pp. 211-223. DOI: 10.2307/2581322.

Lannez, S. (2010). "Optimisation des tournées d'inspection des voies ferroviaires". PhD thesis. Toulouse, INSA. URL: http://www. theses.fr/ 2010ISAT0022 (visited on 05/11/2016).

Lannez, S., Artigues, C., Damay, J., and Gendreau, M. (2015). "A railroad maintenance problem solved with a cut and column generation matheuristic". In: Networks 66.1, pp. 40-56. DOI: 10.1002/net.21605.

Lethanh, N. and Adey, B. T. (2016). "A real option approach to determine optimal intervention windows for multi-national rail corridors". In: Journal of Civil Engineering and Management 22.1, pp. 38-46. DOI: 10.3846/13923730.2014.994030.

Lévi, D. (2001). "Optimization of track renewal policy". In: World Congress on Railway Research, Cologne. UIC. URL: http: / / www . uic . org / 
cdrom / 2001/wcrr2001/pdf / sessions / 2_1_2/467.pdf (visited on 06/18/2014).

Li, R., Wen, M., and Salling, K. B. (2015). "A Predictive Maintenance Model for Railway Tracks". In: Proceedings of IC-ARE 2015. 2015 International Congress on Advanced Railway Engineering. URL: http : / / www . forskningsdatabasen . dk/ en / catalog/2280078077 (visited on $01 / 27 / 2016)$.

Lidén, T. (2014). Survey of railway maintenance activities from a planning perspective and literature review concerning the use of mathematical algorithms for solving such planning and scheduling problems. Tech. rep. Linköping University, Department of Science and Technology. URL: http://urn.kb.se/resolve?urn=urn:nbn:se:liu:diva-111228.

Lingegård, S. (2014). "Integrated Product Service Offerings for Rail and Road Infrastructure : Reviewing Applicability in Sweden". PhD thesis. Linköping University, Department of Management and Engineering. DOI: 10.3384/diss.diva-110015.

Liu, X., Lovett, A., Dick, T., Rapik Saat, M., and Barkan, C. (2014). "Optimization of Ultrasonic Rail-Defect Inspection for Improving Railway Transportation Safety and Efficiency". In: Journal of Transportation Engineering 140.10. DOI: 10.1061/(ASCE) TE.1943-5436.0000697.

Liu, X. and Dick, C. T. (2016). "Risk-Based Optimization of Rail Defect Inspection Frequency for Petroleum Crude Oil Transportation". In: Transportation Research Record: Journal of the Transportation Research Board 2545, pp. 27-35. DOI: $10.3141 / 2545-04$.

Louwerse, I. and Huisman, D. (2014). "Adjusting a railway timetable in case of partial or complete blockades". In: European Journal of Operational Research 235.3, pp. 583-593. DOI: 10.1016/j.ejor.2013.12.020.

Lyngby, N., Hokstad, P., and Vatn, J. (2008). "RAMS Management of Railway Tracks". In: Handbook of Performability Engineering. Ed. by P. K. B. Misra. Springer London, pp. 1123-1145. ISBN: 978-1-84800-130-5, 9781-84800-131-2. URL: http : //link . springer . com/chapter/10 . 1007/ 978-1-84800-131-2_68 (visited on 10/03/2013).

Meier-Hirmer, C. and Pouligny, P. (2008). Impact of preventive grinding on maintenance costs and determination of an optimal grinding cycle. Tech. rep. SNCF, Infrastructure Maintenance Engineering, Paris FranceESREL: UIC. URL: http: //www . uic .org/cdrom/2008/11_wcrr2008/ pdf/S.2.2.4.4.pdf (visited on 06/25/2014).

Meier-Hirmer, C., Sourget, F., and Roussignol, M. (2005). "Optimising the strategy of track maintenance". In: Advances in Safety and Reliability Proceedings of the European Safety and Reliability Conference, ESREL 2005. Vol. 2, pp. 1385-1391. ISBN: 0415383420. 
Miwa, M. (2002). "Mathematical Programming Model Analysis for the Optimal Track Maintenance Schedule". In: Quarterly Report of RTRI 43.3, pp. 131-136. DOI: 10.2219/rtriqr.43.131.

Mohammad Pour, S., Rasmussen, K. M., and Burke, E. K. (2015a). A perturbative clustering hyper-heuristic framework for the Danish railway system. http://orbit.dtu.dk. Department of Management Engineering, Technical University of Denmark. (Visited on 01/04/2016).

Mohammad Pour, S., Stidsen, T. J. R., and Rasmussen, K. M. (2015b). The Preventive Signaling Maintenance Crew Scheduling Problem for European Railway Traffic Management system (ERTMS). http://orbit.dtu.dk. Department of Management Engineering, Technical University of Denmark. (Visited on 01/04/2016).

Murakami, K. and Turnquist, M. A. (1985). "Dynamic Model for Scheduling Maintenance of Transportation Facilities". In: Transportation Research Record 1030. 8, pp. 8-14.

Nemani, A. K., Bog, S., and Ahuja, R. K. (2010). "Solving the Curfew Planning Problem". In: Transportation Science 44.4, pp. 506-523. DOI: $10.1287 / \operatorname{trsc} .1100 .0323$.

Oyama, T. and Miwa, M. (2006). "Mathematical modeling analyses for obtaining an optimal railway track maintenance schedule". In: Japan Journal of Industrial and Applied Mathematics 23, pp. 207-224. DOI: 10.1007/BF03167551.

Pearce, R. H. and Forbes, M. (2016). "Disaggregated Benders Decomposition for solving a Network Maintenance Scheduling Problem". In: arXiv preprint arXiv:1603.02378. URL: http://arxiv.org/abs/1603.02378 (visited on $03 / 14 / 2016$ ).

Peng, F. (2011). "Scheduling of track inspection and maintenance activities in railroad networks". PhD thesis. Urbana, Illinois: University of Illinois at Urbana-Champaign. URL: http : / / hdl . handle . net / 2142 / 24517 (visited on 10/06/2014).

Peng, F. and Ouyang, Y. (2012). "Track maintenance production team scheduling in railroad networks". In: Transportation Research Part B: Methodological 46.10, pp. 1474-1488. DOI: 10.1016/j.trb.2012.07. 004.

Peng, F. and Ouyang, Y. (2014). "Optimal Clustering of Railroad Track Maintenance Jobs". In: Computer-Aided Civil and Infrastructure Engineering 29.4, pp. 235-247. DOI: 10.1111/mice.12036.

Peng, F., Kang, S., Li, X., Ouyang, Y., Somani, K., and Acharya, D. (2011). "A Heuristic Approach to the Railroad Track Maintenance Schedul- 
ing Problem". In: Computer-Aided Civil and Infrastructure Engineering 26.2, pp. 129-145. DOI: $10.1111 / \mathrm{j} .1467-8667.2010 .00670 . \mathrm{x}$.

Peng, F., Ouyang, Y., and Somani, K. (2013). "Optimal routing and scheduling of periodic inspections in large-scale railroad networks". In: Journal of Rail Transport Planning \& Management 3.4, pp. 163-171. DOI: 10.1016/j.jrtpm.2014.02.003.

Podofillini, L., Zio, E., and Vatn, J. (2006). "Risk-informed optimisation of railway tracks inspection and maintenance procedures". In: Reliability Engineering 86 System Safety 91.1, pp. 20-35. DOI: 10.1016/j.ress . 2004.11.009.

Pouryousef, H., Teixeira, P., and Sussman, J. (2010). "Track Maintenance Scheduling and Its Interactions With Operations: Dedicated and Mixed High-Speed Rail (HSR) Scenarios". In: 2010 Joint Rail Conference. ASME, pp. 317-326. ISBN: 978-0-7918-4907-1. DOI: 10.1115/JRC201036125 .

Quiroga, L., Antoni, M., and Schnieder, E. (2011). "Heuristic based track maintenance scheduling optimisation". In: 9th World Conference on Railway Research. Lille. URL: http : / /www . railway-research . org/ IMG/pdf/g2_schnider_eckehard.pdf (visited on 06/25/2014).

RailNetEurope (2013a). Glossary of Terms related to Railway Network Statements. URL: http : / / www.rne.eu/ns_glossary.html (visited on $03 / 03 / 2014$ ).

RailNetEurope (2013b). Guidelines for Coordination / Publication of Works and Possessions. http://www.rne.eu. (Visited on 03/03/2014).

RTRI. Railway Technical Terminology Dictionary. URL: http://yougo . rtri.or.jp/dic/en/main.jsp (visited on 09/26/2013).

Ruffing, J. A. (1993). "An analysis of the scheduling of work windows for railroad track maintenance gangs". In: Proceedings of the Transportation Research Forum. Vol. 35, pp. 307-314. URL: http://trid.trb.org/ view. aspx?id=551772 (visited on 06/25/2014).

Santos, R., Fonseca Teixeira, P., and Pais Antunes, A. (2015). "Planning and scheduling efficient heavy rail track maintenance through a Decision Rules Model". In: Research in Transportation Economics 54, pp. 20-32. DOI: $10.1016 /$ j.retrec.2015.10.022.

Shang, H. (2015). "Maintenance modelling, simulation and performance assessment for railway asset management". PhD thesis. Université de Technologie, Troyes (UTT). URL: http://www.theses.fr/2015TROY0022/ document (visited on 12/02/2015).

Trafikverket (2012). Organisering av underhåll av den svenska järnvägsinfrastrukturen. Swedish. Tech. rep. TRV2012/63556, p. 66. 
Transport analysis (2015). Train performance - Official Statistics of Sweden. URL: http : / / trafa . se / en / rail-traffic/train-performance/ (visited on $04 / 20 / 2016$ ).

Vale, C., Ribeiro, I., and Calçada, R. (2010). "Application of a maintenance model for optimizing tamping on ballasted tracks: the influence of the model constraints". In: The second international conference on engineering optimization. URL: http: //www1.dem . ist . utl.pt/engopt2010/ Book_and_CD/Papers_CD_Final_Version/pdf / 10/01197-01 . pdf (visited on 10/02/2013).

Vale, C., Ribeiro, I., and Calçada, R. (2011). "Scheduling tamping through global optimization of maintenance costs". In: Proceedings of the 9th World Congress on Railway Research, WCRR. URL: http : / / www . railway-research . org / IMG / pdf / e2_vale_cecilia.pdf (visited on $06 / 25 / 2014)$.

Vale, C., Ribeiro, I. M., and Calçada, R. (2012). "Integer Programming to Optimize Tamping in Railway Tracks as Preventive Maintenance". en. In: Journal of Transportation Engineering 138.1, pp. 123-131. DOI: 10.1061/(ASCE) TE.1943-5436.0000296.

Vansteenwegen, P., Dewilde, T., Burggraeve, S., and Cattrysse, D. (2015). "An iterative approach for reducing the impact of infrastructure maintenance on the performance of railway systems". In: European Journal of Operational Research 252.1, pp. 39-53. DOI: 10.1016/j.ejor. 2015. 12.037.

Veelenturf, L. P., Kidd, M. P., Cacchiani, V., Kroon, L. G., and Toth, P. (2015). "A Railway Timetable Rescheduling Approach for Handling Large-Scale Disruptions". In: Transportation Science. DOI: 10.1287 / trsc. 2015.0618.

Wen, M., Li, R., and Salling, K. B. (2015). "Optimization of Preventive Condition-Based Tamping for Railway Tracks". In: EJOR - preprint. URL: http : / / orbit . dtu . dk / fedora / objects / orbit : 140763 / datastreams/file_112046026/content (visited on 07/13/2015).

Wikipedia. Glossary of rail transport terms. URL: http://en.wikipedia. org / w / index . php ? title=Glossary _ of _ rail_transport _ terms \& oldid=582560072 (visited on 11/25/2013).

Zante-de Fokkert, J. I. van, Hertog, D. den, Berg, F. J. van den, and Verhoeven, J. H. M. (2007). "The Netherlands Schedules Track Maintenance to Improve Track Workers' Safety". In: Interfaces 37.2, pp. 133-142. DOI: 10.1287 /inte. 1060.0246.

Zhang, T., Andrews, J., and Guo, B. (2013a). "A Simulated Petri-net and Genetic Algorithm Based Approach for Maintenance Scheduling for a Railway System". In: Advances in Risk and Reliability Technology Sym- 
posium. 20th AR2TS, Nottingham. URL: http://beta.nottingham.ac. uk/engineering/conference/ar2ts/documents/08.pdf (visited on $10 / 02 / 2014)$.

Zhang, T., Andrews, J., and Wang, R. (2013b). "Optimal Scheduling of Track Maintenance on a Railway Network". In: Quality and Reliability Engineering International 29.2, 285-297. DOI: 10.1002/qre.1381.

Zhao, J., Chan, A. H. C., and Burrow, M. P. N. (2006a). "Reliability analysis and maintenance decision for railway sleepers using track condition information". In: Journal of the Operational Research Society 58.8, pp. 10471055. DOI: $10.1057 /$ palgrave.jors. 2602251.

Zhao, J., Chan, A. H. C., and Burrow, M. P. N. (2009). "A genetic-algorithmbased approach for scheduling the renewal of railway track components". In: Journal of Rail and Rapid Transit 223.6, pp. 533-541. DOI: 10.1243/ 09544097 JRRT273.

Zhao, J., Chan, A., Stirling, A., and Madelin, K. (2006b). "Optimizing Policies of Railway Ballast Tamping and Renewal". In: Transportation Research Record: Journal of the Transportation Research Board 1943, pp. 50-56. DOI: 10.3141/1943-07. 


\section{Papers}

The articles associated with this thesis have been removed for copyright reasons. For more details about these see:

http://urn.kb.se/resolve?urn=urn:nbn:se:liu:diva-128780 